\title{
Application of the cost-optimal methodology to urban renewal projects at the territorial scale based on statistical data. A case study in Spain.
}

\author{
Sergi Aguacila, Sophie Lufkina, Emmanuel Rey ${ }^{a}$, Albert Cuchib
}

(a) Laboratory of Architecture and Sustainable Technologies (LAST), Ecole polytechnique fédérale de Lausanne (Switzerland).

(b) Research group on Architecture, energy and environment (AIEM), Department of Architectural Technology, Vallès School of Architecture (ETSAV), Universitat Politècnica de Catalunya (Spain).

\section{Abstract}

As tomorrow's cities are already largely built, many strategies stress the importance of urban renewal processes to address current energy issues. This paper focuses on the Spanish residen ial juilding stock built until 2001, which has a low level of energy performance.

Considering the current economic crisis, the future lies in renovating the buil environment, which holds a significant energy-saving potential. This potential is here quantif ed by applying the cost-optimal methodology, initially proposed by the Energy Performance of B illi gs Directive, and which calculates costoptimal levels of minimum energy performance requiremen $s$ at the building and component scale.

The originality of our study lies in the application on this methodology at the territorial scale, comparing different retrofitting scenarios by scaling-up building-scale results through an archetypal approach. We also describe an Excel-based tool allowing two types of studies: (i) at the building scale, for one archetype in a particular climatic zone; (ii) at the territorio scale, to have an overview of all building archetypes and climatic zones simultaneously. Results incl de conomic aspects, energy consumption and savings and associated emissions.

The outcome can help con struction-sector firms adapt their business plan, while also providing stakeholders with decision-support o promote a sustainable renewal of the building stock.

Keywords: cost-o timal methodology; cost-effective strategies; urban renewal; sustainable retrofit; environme tal assessment; decision-making tool; residential building; sustainable architecture. 


\section{Introduction}

\subsection{European and Spanish building stock}

One of the top priorities regarding the built environment in European countries is to reduce energy consumption and greenhouse gas (GHG) emissions and increase the use of renewable energy [1-5] . Due to the low replacement rate of existing buildings - about 1-3\% per year in EU countries [6] - the majority of buildings that will exist in 2050 is already built, with many of them having a low level of energy performance [7]. In this context, the retrofit of existing buildings offers significant opportunities for reducing energy consumption and GHG emissions [8]. In fact, the International Energy Agency (IEA) estimates that the potential energy savings for 2050 are of about 1,509 million tonnes of oil equivalent [9], with a 50-75\% saving when considering only the improvement of the building envelope [10]. It therefore sems clear that the residential building stock in EU-27 offers high potential for energy efficiency gains $1: 1,12]$. This large potential energy saving is particularly relevant to the Spanish context [7], where most residential buildings were constructed before 2001, when thermal regulations were modest [13-18].

According to the Energy Performance Certification (EPC) in Spain, which rates buildings from A (best) to $G$ (worst), 96\% of the certified 1.4 million existing buildings are below the current legal requirements set at an EPC level C [19]. The EPC rate depends on the type of building and the climatic zone where it is located. In general, the different levels follow a linear dependency. a building with the lowest qualification consumes ten times more than a building with the highest level of ocrformance [20,21].

The residential building stock as a whole emits about $35 \mathrm{kgCO} / \mathrm{m}^{2}$ per year in terms of primary energy (PE) consumption [22], a value that is far from the ambitious objectives of the EU horizon 2050 for new and existing buildings of around $3 \mathrm{kgCO} / \mathrm{m}^{2}[23$.

However, by considering only envelope retrofitting, it would be possible to reduce the energy used by residential buildings up to $25 \%$ by 2020 [24]. For the 2050 horizon, the total savings could reach $71 \%$ in terms of energy and $73 \%$ terms of GHG emission [22]. These values highlight that it is theoretically possible to achie e the EU's $20 \%$ energy-saving target for 2020 , as well as the long term $80-95 \%$ GHG emissions red ction target for 2050.

\subsection{Eu ropean and Spanish regulations and cost-optimal methodology}

In response to the strong demand for housing, the construction of residential buildings in Spain underwent unprecedented growth, especially between 1960 and 2001 [13,14]. Unfortunately, these buildings were designed either without ensuring a minimum level of construction quality, in terms of comfort and energy efficiency, or relying on insufficiently restrictive regulations.

The first regulation seeking to improve the energy performance of buildings resulted from the energy crisis of 1973: the NBE-CT-79 - Thermal Conditions in Buildings, published on July 6, 1979 [25]. However, this first 
regulation did not specify a target for reducing energy consumption. It simply established a set of acceptable constructive solutions, without defining a protocol for controlling the quality of the building envelope.

The most important change appeared with the European Directive 2002/91/EU concerning the energy efficiency of buildings. The transposition of this Directive in Spain is reflected by Royal decree (RD) 314/2006 - Technical Building Code (CTE) [26], RD 1027/2007 - Thermal facilities in Buildings (RITE) [27] and RD 47/2007 - Energy Performance Certification (EPC) protocol for new buildings [28]. The mission of these new standards was to regulate all construction parameters and to define energy limits and steps to follow for the energy certification of new constructions $[18,27,28]$. This situation put the existing building stock in the spotlight, due to its enormous energy consumption and GHG emissions [7].

With the focus placed on the continuous increase in the demand for new residential buildirns un until 2001, only recently has there been specific Spanish legislation in terms of building rehabilitation. The three most recent regulations appeared in 2013 [18]:

- $\quad$ RD 235/2013 - New protocol for the EPC to include existing buildings 1201

- CTE 2013 - Updated CTE for regulating the energy requirement of new and existing buildings [18].

- $\quad$ RD 8/2013 - Law to promote urban renewal projects [29].

These changes in the regulatory framework try to respond $c 0$ the requirements of the European Directive 2010/31/EU, which establishes that all public and privateiy owned buildings must be nearly Zero Energy Building (nZEB) from December 312018 and 020 respectively. In this directive, the cost-optimal methodology was mentioned for the first time $11_{1}$. - initially, this methodology was proposed by the EU to study different building retrofitting scena 10 . It consists in a multi-criteria assessment that allows comparing different levels of intervention unde, various macro-economic scenarios, in terms of cost-effective strategies and energy and environmental savings [8,12,17,22,30-33].

In parallel, the evolution of [IU directives continued. In 2012, the 2012/27/EU Directive was presented [34]. It defines the PE and GHO m s sions savings to be achieved, and requires all EU member states (MS) to define specific strategies to acmeve those objectives. As a result, in the Spanish context, the current legislation does not yet meet the requirements of the latest EU directives.

Therefore, new regulatory changes are necessary in the short term in order to reach the required level, because all EU countries should have submitted plans and regulations for the promotion of nearly nZEB, as well as measures to promote building energy rehabilitation projects following the cost-optimal methodology to ensure the viability of the improvement strategies $[17,22,35]$.

\subsection{Overview of study}

Attempting to address these issues, this research proposes an application of the cost-optimal methodology at the territorial scale to estimate the energy-saving potential of the residential buildings built before 2001 in Spain. The originality of this study lies in the application of this methodology at a large scale, using statistical 
and population census data and taking into account the 12 climatic zones of the Spanish territory. The paper moreover describes an Excel-based calculation tool, developed to enable professionals to make strategic decisions by helping them select the best strategy for achieving the European requirements for 2020 according to the nZEB. This research is based on the work conducted during the Master thesis of the first author [36], which represents the main source for the content of this manuscript.

The structure of the paper is articulated in seven sections: (1) introduction, (2) literature review, (3) definition of the main objectives, (4) proposed methodology to carry out the development of a decisionmaking tool, (5) presentation of the main results through a case study in Spain, testing different renovation scenarios and different temporal horizons, (6) discussion of results, and (7) cond sions and recommendations to promote energy renovation of the building stock.

\section{Literature review}

The EPBD recast [17] proposes that all MS establish a comparative framework to alculate cost-optimal levels of minimum energy performance requirements for buildings and building components, using the costoptimal methodology. Table 1 summarizes how this methodology has peen employed in various studies conducted in a specific climatic context for investigating renovation trategies over existing buildings.

In terms of scale, we observe that a majority of applications of the methodology have been at the building or component scale, especially to compare different con truc ive solutions and construction materials or to optimize the insulation thicknesses of the buildin envelope $[8,12,32,33,37-42]$. When at the building scale, studies typically consider only one specific typolog for a given period of time or year (e.g. multi-family house of 1960-1990 [8]).

To analyse the existing building(s), nd cccording to the purpose of the study, different approaches are used. The majority of the publication $s$ nake a classification of the building stock in different categories using the concept of 'reference builaing' wased on real building examples in a specific context $[40,43,44]$. This concept is applied for example in the Typology Approach for Building Stock Energy Assessment (TABULA) project [45] with the aim to have harmonized database of existing buildings at the European level. Unfortunately, this database presents a lack of information for specific countries (e.g. Spain) and does not contain enough informatio to depict the whole building stock according to climatic zones.

Another approach consists in using statistical data to extract statistically relevant parameters $[32,46,47]$. This information can be used, as done by Schwehr et al. [48], to define 'building typologies' within the building stock, where each typology corresponds to a building with the same set of parameters, including period of construction, context, construction characteristics, and other features related to the assessment objectives. Making an aggregation by groups using, for example, the construction period as the main parameter can then allow obtaining results for a larger scale [49]. 
Another statistics-based concept is that of 'archetype', defined as a theoretical model that represents each of the different building typologies [50]. This method is used to classify the building stock according to different parameters such as climatic conditions, construction period and context. Each archetype definition represents a major type of dwelling that can be used as input data for energy simulation [51]. Then, the estimation of energy consumption and GHG emissions of each archetype can be scaled-up to be representative of the regional or national housing stock. This is done by multiplying the results by the number of dwellings (given by the statistical data) which fit the description of each archetype [52]. This scaling-up method can also be understood as a bottom-up approach for representing the building stock.

The general purpose of application of the cost-optimal methodology is to enable the colparison of scenarios integrating different energy-efficient measures (EEM), or to identify the most cost-optimal combination of EEM. In most cases, the EEM consist of passive strategies, while â fem sudies have considered a mix of passive and active strategies as well as renewable energy technologies (RET) $[42,43,53]$.

The multi-criteria analyses include outputs such as the Net Present Value (NPV), g obal cost, GHG emissions and energy savings, sometimes resulting from a full Life Cycle Assessinen (LCA) [23,32]. However, all assessments are based on a fixed horizon period and show a uniq value for each output as opposed to a temporal profile.

Looking at the whole workflow adopted in the different publications, we have identified two main different methods: simplified and complex.

The simplified methods $[40,54]$ propose a simple way to calculate the energy demand and an expert system to assist the decision-making, assuming a cetam level of error or uncertainty in the results. These methods are commonly applied at larger scâles, for instance to study a regional building stock taking into account different climatic conditions using the Degree Days simplified methodology.

The complex methods $[32,53,-5]$ propose advanced simulation-based multi-objective optimisation, using a combination of tools (Enere plus, TRNSYS, MatLab) and genetic algorithms. They are commonly applied at a more detailed scie, e.s. to define the optimal choice of materials at the building scale, and try to be as accurate as possib/e $[52,56,57]$. 
Table 1: Literature review: implementation of the cost-optimal methodology in renovation projects considering scale, building typology, context and climate conditions, along with main objective of the application. See list of abbreviations at the end of the manuscript.

\begin{tabular}{|c|c|c|c|c|}
\hline Ref. & Building typology and database & Context & Considered measures & Main objectives \\
\hline [43] & $\begin{array}{l}\text { Single-family (SF) and multi- } \\
\text { family (MF) houses classified in } \\
\text { three construction periods (pre- } \\
\text { 1980, 1981-2000 and after 2000). } \\
\text { TABULA database. } \\
\end{array}$ & $\begin{array}{l}\text { Greece, three climatic } \\
\text { zones defined by HDD. }\end{array}$ & $\begin{array}{l}\text { Passive (add thermal insulation and } \\
\text { replace windows), active (new boiler) and } \\
\text { RET (ST panels for domestic hot water } \\
\text { (DHW)) according to two scenarios } \\
\text { (standard and ambitious). }\end{array}$ & $\begin{array}{l}\text { Overview of total consumption and } \mathrm{CO}_{2} \text { emissions of } \\
\text { building stock and estimation of saving potentials. Use } \\
\text { of payivaci per od (PBP). }\end{array}$ \\
\hline [55] & $\begin{array}{l}\text { Semi-detached SF house, built in } \\
1945 .\end{array}$ & $\begin{array}{l}\text { Portugal, no specified } \\
\text { climatic zones. }\end{array}$ & $\begin{array}{l}\text { Three groups of measures, including } \\
\text { passive (type of insulation) and RET (ST } \\
\text { panels for DHW). }\end{array}$ & $\begin{array}{l}\text { Comparison between different construction materials. } \\
\text { Based on multi-objective evaluation using GenOpt and } \\
\text { Tchebycheff optimization technique. }\end{array}$ \\
\hline [50] & $\begin{array}{l}\text { Nine residential buildings built } \\
\text { before 1960, 1960-1990 and } \\
\text { after 1990. Concept of } \\
\text { Archetype. CYPE Engineers } \\
\text { database. }\end{array}$ & $\begin{array}{l}\text { Portugal, Lisbon climate } \\
\text { data conditions. }\end{array}$ & $\begin{array}{l}\text { Passive strategies (insulation thickn ss } \\
\text { and windows), six options of HVAC } \\
\text { systems with solar thermal panels. }\end{array}$ & $\begin{array}{l}\text { Use of cost optimal methodology to define range of } \\
\text { optimal U-values for walls, roofs and windows. }\end{array}$ \\
\hline [58] & $\begin{array}{l}\text { Results of } 26,000 \text { renovated } \\
\text { dwellings. }\end{array}$ & Spain (Madrid). & $\begin{array}{l}\text { Passive (add thermail nsulation and } \\
\text { replace windows }\end{array}$ & $\begin{array}{l}\text { Application of four public plans to help owners replace } \\
\text { windows by more efficient ones; show that incomes } \\
\text { due to value-added tax (VAT) (related to renovation } \\
\text { work) is superior to total amount of public aids to } \\
\text { dwelling owners. }\end{array}$ \\
\hline [40] & $\begin{array}{l}\text { MF buildings, from } 1946 \text { to } 1960 \text {, } \\
\text { using TABULA database. }\end{array}$ & $\begin{array}{l}\text { Italy, climates with } 2100 \\
\text { and } 3000 \text { HDD. }\end{array}$ & $\begin{array}{l}\text { Si g ELM taking into account passive, } \\
\text { act Ve, RET and HVAC systems strategies. }\end{array}$ & $\begin{array}{l}\text { Optimal value of design parameters (single strategies), } \\
\text { comparing energy performance and global cost. }\end{array}$ \\
\hline$[46]$ & $\begin{array}{l}\text { A SF house, statistical census } \\
\text { data } 2001 .\end{array}$ & $\begin{array}{l}\text { Italy (Cesena), } 2256 \\
\text { HDD, according to Italia? } \\
\text { standards. }\end{array}$ & $\begin{array}{l}\text { Four EFM (insulation, windows, new } \\
\text { biler and solar thermal panels for DHW). }\end{array}$ & $\begin{array}{l}\text { Comparison of energy savings between four } \\
\text { construction periods for same reference building (1950, } \\
1970,1980 \text { and 1995). }\end{array}$ \\
\hline [59] & Construction level. & $\begin{array}{l}\text { Greece (Athens), } \\
\text { (Rome) and Srain } \\
\text { (Madrid), 'oased on HDD } \\
\text { and CDD. }\end{array}$ & $\begin{array}{l}\text { Thickness of insulation as optimisation } \\
\text { parameter. }\end{array}$ & $\begin{array}{l}\text { Find optimum balance between cost, energy savings } \\
\text { and thickness of insulation. }\end{array}$ \\
\hline$[42]$ & $\begin{array}{l}\text { Five reference office public } \\
\text { buildings. }\end{array}$ & $\begin{array}{l}\text { Italy Port gal, Romania, } \\
\text { Sp in a hl Greece. }\end{array}$ & $\begin{array}{l}\text { Passive (insulation, windows, shading } \\
\text { systems), active (electricity-based } \\
\text { systems, lighting) and RET (solar thermal } \\
\text { and photovoltaic panels). }\end{array}$ & $\begin{array}{l}\text { Find optimal global cost for renovation projects in } \\
\text { different countries }\left(300-550 € / \mathrm{m}^{2}\right) \text {. }\end{array}$ \\
\hline
\end{tabular}


Table 1 (cont.): Literature review: implementation of the cost-optimal methodology in renovation projects considering scale, building typology, context and climate conditions, along with main objective of the application. See list of abbreviations at the end of the manuscript.

\begin{tabular}{|c|c|c|c|c|}
\hline Ref. & Building typology and database & Context & Considered measures & Main objectives \\
\hline [53] & Reinforced concrete MF building. & $\begin{array}{l}\text { Italy, no specified } \\
\text { climatic zones. }\end{array}$ & $\begin{array}{l}\text { Eight design variables (coating and } \\
\text { insulation of roof, insulation on walls, } \\
\text { mechanical ventilation system, } \\
\text { temperature set points, double glazing, } \\
\text { and HVAC systems). }\end{array}$ & PE consumption versus comfort criterion optimization. \\
\hline [8] & $\begin{array}{l}\text { MF building (reference building } \\
\text { period 1960-1990). }\end{array}$ & $\begin{array}{l}\text { Portugal, Lisbon climate } \\
\text { conditions. }\end{array}$ & $\begin{array}{l}\text { Passive strategies: improving windows, } \\
\text { adding insulation (roof, floor and walls). }\end{array}$ & $\begin{array}{l}\text { Comparison between global cost and PE consumption } \\
\text { of aifferent scenarios. }\end{array}$ \\
\hline$[41]$ & MF building, built in 1970 . & Spain (Tudela). & $\begin{array}{l}\text { Three scenarios (minimum requirement } \\
\text { of current regulations, deep retrofit and } \\
\text { a combination with RET strategies }\end{array}$ & $\begin{array}{l}\text { ECC comparison (global cost versus } \mathrm{CO}_{2} \text { emissions and } \\
\text { PE consumption). }\end{array}$ \\
\hline [39] & $\begin{array}{l}\text { MF building (specific case study) } \\
\text { built in } 1931 .\end{array}$ & $\begin{array}{l}\text { Vienna, no specified } \\
\text { climatic conditions. }\end{array}$ & Evaluation of different types of in sulation. & $\begin{array}{l}\text { LCC though multi-criteria assessment taking into } \\
\text { account economy, ecology and cultural history. }\end{array}$ \\
\hline [47] & $\begin{array}{l}\text { Six MF buildings, built 1966-1982 } \\
\text { Statistics database. }\end{array}$ & Estonia, cold climate. & $\begin{array}{l}\text { Passive (insulation, windows) and active } \\
\text { (ventilation and heating system). Three } \\
\text { governmental su sid es level (15, } 25 \text { and } \\
35 \% \text { ). }\end{array}$ & $\begin{array}{l}\text { Comparison between investment using NPV and energy } \\
\text { savings for } 2030 \text { horizon. }\end{array}$ \\
\hline [60] & $\begin{array}{l}\text { SF house, non-detailed case } \\
\text { study. }\end{array}$ & $\begin{array}{l}\text { Belgium context } \\
\text { (without taking into } \\
\text { account different } \\
\text { climatic zones). }\end{array}$ & $\begin{array}{l}\text { Passive an ac ive strategies without } \\
\text { specific de jalis. }\end{array}$ & $\begin{array}{l}\text { General approach, implementation of decision-making } \\
\text { tool (www.renofase.be). }\end{array}$ \\
\hline [12] & $\begin{array}{l}\text { Eight primary school buildings, } \\
\text { with different ages and } \\
\text { construction types. }\end{array}$ & $\begin{array}{l}\text { Austria, no specified } \\
\text { climatic conditions. }\end{array}$ & $\begin{array}{l}\text { Varius optimization variables (passive } \\
\text { and active strategies). }\end{array}$ & $\begin{array}{l}\text { Optimization using LCC assessment comparing heating } \\
\text { energy demand versus NPV. }\end{array}$ \\
\hline [61] & $\begin{array}{l}\text { MF building (three case studies } \\
\text { with same geometry but } \\
\text { different envelope properties) }\end{array}$ & $\begin{array}{l}\text { Turkey (Istanbul, A ntaira } \\
\text { and Erzurum) } \\
\text { Represent } \mathrm{Cr} \text { ee of five } \\
\text { main climates in } \\
\text { counth }\end{array}$ & $\begin{array}{l}\text { Mainly passive strategies (envelope } \\
\text { building improvements). }\end{array}$ & $\begin{array}{l}\text { Comparison between global cost and PE consumption } \\
\text { of different scenarios. }\end{array}$ \\
\hline [32] & $\begin{array}{l}\text { Representative MF buildings, } \\
\text { period 1950-1980, population } \\
\text { and housing census. }\end{array}$ & Sp in (Madrid). & $\begin{array}{l}\text { Three scenarios according to current } \\
\text { practice, current regulation and passive } \\
\text { house label. }\end{array}$ & $\begin{array}{l}\text { Optimization method using Pareto front, analysing LCC } \\
\text { and LCA. }\end{array}$ \\
\hline
\end{tabular}


The novel application of the cost-optimal methodology that we propose takes into account these two levels of complexity by defining a pre-simulated energy demand database of seven archetypes in 12 climatic zones, obtained using the official software (CE3X) [62] for generating EPC in Spain. Using this software allows us to compare our results to the EPC database of real buildings [7], in order to test the accuracy of the results at the territorial level, which is our target scale. Therefore, as Spain's EPC registry becomes more complete [19], our database may be updated without conflicts.

The pre-simulated database is generated by building upon the work conducted by the Rehabilitation Working Group (GTR) [63]. The GTR, who's objective is to facilitate the transformation of Spain's building sector, has published three main reports that detail the Spanish legislation, examine the exis ing housing stock, and propose a general operational framework for the building renovation sector in Spain [64-66]. In our work, the building typologies along with their parametric details identified by the GTR from the statistical census data of 2001 [13] are used to define our archetypes. This approach allows us to obtain a more detailed, precise and context-specific database, compared for instance to TABULA 45 ?

Pre-simulated energy demand data are obtained for the current statis oi each archetype, as well as following two retrofitting strategies (minor and deep) in which passi e strategies are considered. Active systems and solar-based RET are then included to define complete packages of mixed strategies.

In addition to the standard cost-optimal methodology static utputs, results from a Life-Cycle Analysis (LCA) and Cost (LCC) analysis are presented to provide emporal representation of the different retrofitting scenarios, considering the moment of application of each EEM. The final contribution of this work is the implementation of the whole workflow into a ncel tool, for use by professionals such as planners and policy-makers.

\section{Objectives}

This work focuses on the resiantial building stock, which represents $75 \%$ of the built surfaces in Europe [22]. While our stud incluces archetypes built before 1960, we are specifically concerned with buildings constructed over period of 40 years from 1961-2001, when the rhythm of dwelling construction was very high. As show in Figure 1, over 16 million dwellings were built on the Spanish territory during this period; 9.2 million Jetween 1961 and 1980 and 6.8 million between 1981 and 2001 [13,14].

This large building stock should have already been renewed, but Spain is suffering (since 2008) from a deep economic crisis [64] that has particularly affected the building sector [67]. This is why all buildings with more than 40 years have not had the opportunity to be refurbished, as reflected by the energy performance certificate database from the Catalan Institute of Energy (ICAEN) [7]. As detailed in sections 4.1-4.3, obtaining from the census database $[13,14]$ the type of building, its construction period and climate conditions provides enough information to know the main construction characteristics $[51,52,68]$ and make a reliable estimation of the energy efficiency of the entire stock of housing constructed during that period (1960-2001). 


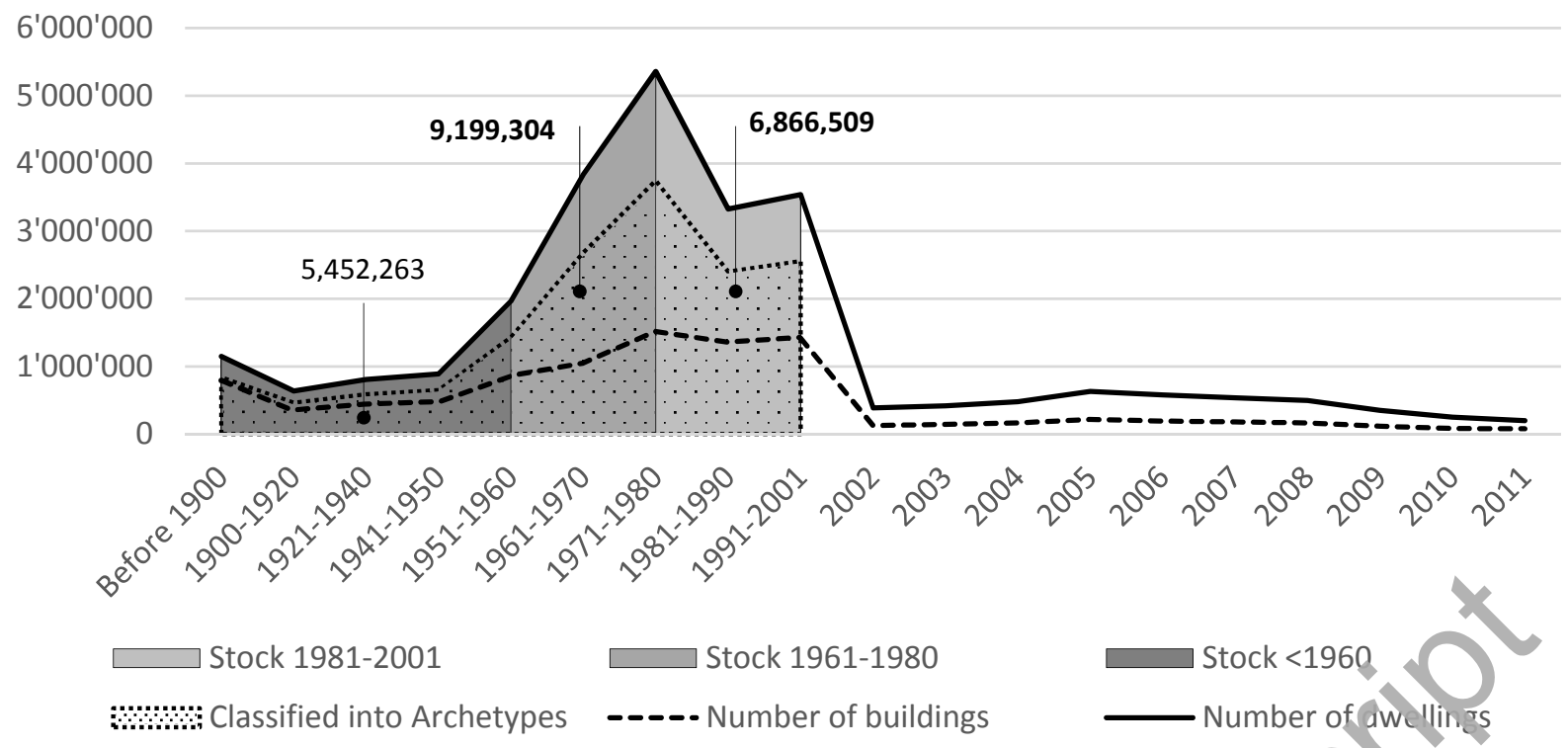

Figure 1: Total construction in Spain until 2011 (in number of residential buildings and dwellings) [13,14]

The ultimate objective of this work is to support stakeholders in the field on urban planning in making strategic medium/long-term decisions towards a sustainable urban renewar piocess of the building stock. To do so, we propose a decision-making tool implemented in Excel and hat integrates a new systematic approach for carrying out studies at different scales: (i) at the uilding scale, for comparing different sets of EEM strategies for one type of housing in a particular climatic zone; (ii) at the territorial scale, scaling-up from the individual archetype analysis, for comparing di ieren sets of EEM strategies applied to all types of buildings in all climatic zones simultaneously. The results include economic and financial aspects, consumption and energy savings, associated GHG enissions, embodied energy, and compliance with the nZEB targets of each renovation scenario 3140,09$]$.

According to the spatial scale of the s.vdy, cifferent types of analyses can be conducted:

- Identify which strategy is most suriable for each type of building, climatic zone and macroeconomic scenario;

- Evaluate the number of households likely to be refurbished through a minor/deep retrofit;

- Evaluate the cost of subsidy required and the potential energy savings;

- Obtain an overview indicating the cost-effective strategies, to help define the business plan of companies in the const uc ion sector;

- Identify the amount of surface that could be rehabilitated by architects specialized in energy efficiency and rehabilitation.

Ultimately, this information shall support the achievement of the European requirements for 2050 horizon $[17,34]$ in the Spanish context.

\section{Methodology}

Our approach (Figure 2) starts from the categorization of the existing housing stock based on the climatic zone and the period of construction as detailed in sections 4.1-4.3. Scenarios of retrofitting interventions are 
then defined, from EEM (passive and active including solar-based RET) strategies described in 4.4, with the aim of achieving nearly Zero Energy Buildings (nZEB) according to the adopted definition presented in section 4.5. Section 4.6 lists the outputs of our multi-criteria evaluation, which is conducted for each scenario through the developed decision-making tool described in section 4.7.

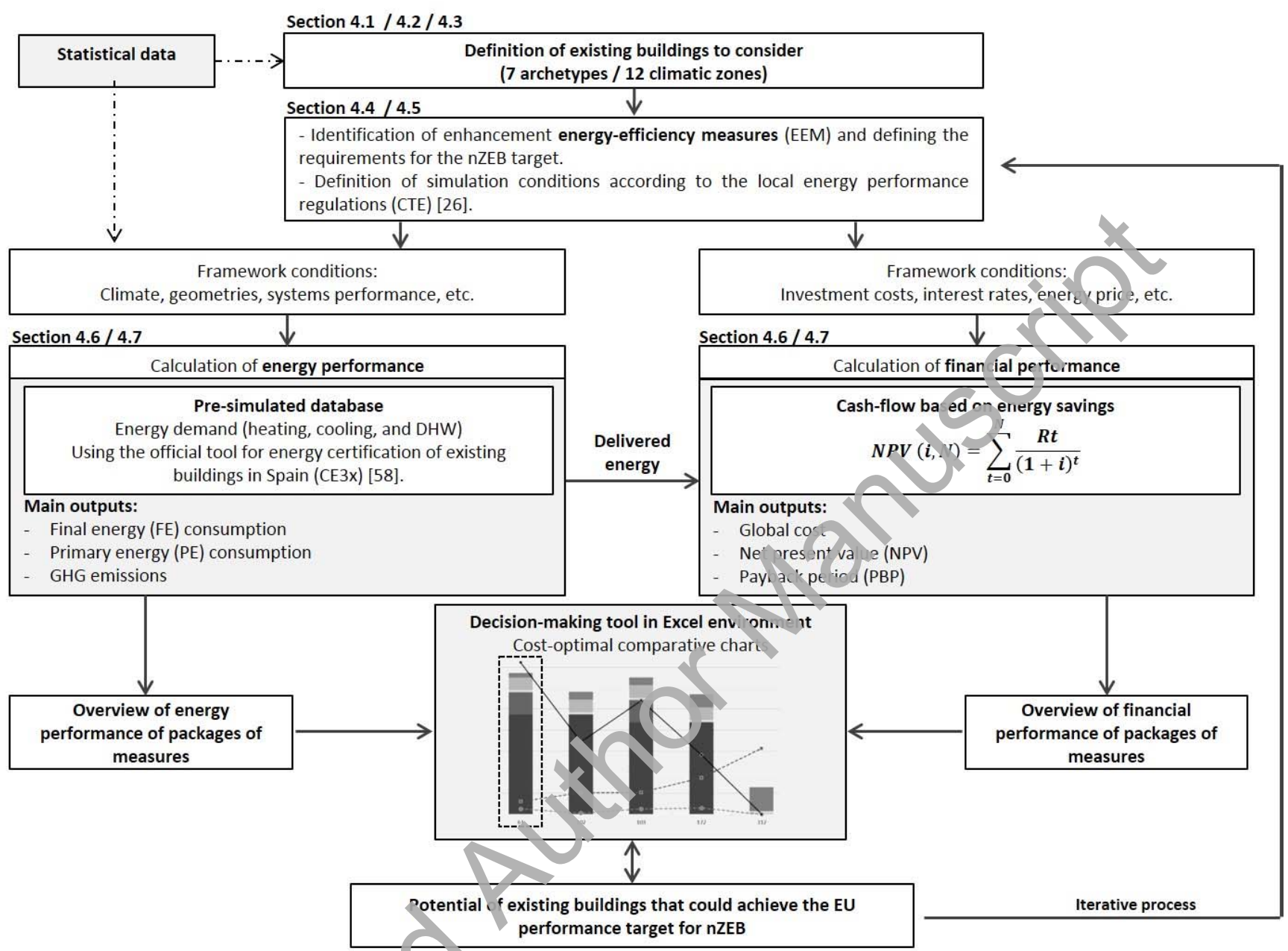

Figure 2: Flowchart of the research $n$ etr oaviogy with corresponding section. Adapted from the cost-optimal methodology chart [69] and using official software for $\mathrm{PC}$ i $S$ ain (CE3X) [62].

\subsection{Housing sto-'(Arcietypes)}

As seen in sec ion 2, the analysis of the building stock can be realised through different approaches, namely reference by ilings (corresponding to real building examples) [44], building typologies (corresponding to common buildings) [48], and archetypes (defined as a theoretical model representing different building typologies) [50]. We propose to use the archetypes approach that allows us to scale-up the results from the building to the territorial scale.

We have defined our archetypes specifically for energy simulations using, as Parekh [51] recommends, a geometry and envelope parametrization, defining building typology, construction period and climate conditions as the main classification parameters, since these three values provide enough guidelines to define the archetypes $[51,52,68]$. 
The categorisation of the residential building stock up to 2001 in Spain has been carried out based on reports from the GTR $[64,65]$ and determining each typology through statistical data $[13,14]$, using the frequency of a building type and identifying the most relevant ones, as recommended by Schwehr et al. [48]. Finally, we managed to classify more than 15 million existing dwellings (Figure 1) in seven archetypes (Table 2).

Table 2: Building archetype definition and number of existing dwellings classified, respecting the original codification made by the GTR and exposed in their reports $[65,68]$.

\begin{tabular}{|c|c|c|c|}
\hline Archetype & Definition & Construction features & $\begin{array}{c}\text { Numbers of } \\
\text { classified dwellings }\end{array}$ \\
\hline$\widehat{>}$ & $\begin{array}{l}\text { SF housing in rural areas built before } \\
1960 .\end{array}$ & $\begin{array}{l}\text { Built with traditional solid and thick walls, } \\
\text { pitched roof with a ventilated chamber and } \\
\text { ground floor directly in contact with the } \\
\text { ground. }\end{array}$ & $2,226,973$ \\
\hline \begin{tabular}{|c|} 
B \\
$<1960$
\end{tabular} & $\begin{array}{l}\text { MF buildings over four floors and } \\
\text { located in dense urban environments } \\
\text { and built before } 1960 \text {. }\end{array}$ & $\begin{array}{l}\text { Built with solid walls, flat roof, suspended slab } \\
\text { ground floor, and usually a commercial activity } \\
\text { developed on the ground floor. }\end{array}$ & \\
\hline$\overbrace{1961-1980}$ & $\begin{array}{l}\text { Rural houses built in the period } \\
\text { between } 1961 \text { and } 1980 .\end{array}$ & $\begin{array}{l}\text { Built with cavity walls, pitched roof wit' out all } \\
\text { chamber, and outdoor ventilated cra wi spare } \\
\text { under ground floor. }\end{array}$ & $1,864,213$ \\
\hline \begin{tabular}{|l|}
$\mathrm{D}, \mathrm{E}, \mathrm{F}$ \\
\\
$1961-1980$
\end{tabular} & $\begin{array}{l}\text { MF dwellings in detached buildings } \\
\text { either in rural or urban areas, built } \\
\text { between } 1961 \text { and } 1980 .\end{array}$ & $\begin{array}{l}\text { Built with cavity walls, flat roo and outdoor } \\
\text { ventilated crawl space under round floor. }\end{array}$ & $4,566,242$ \\
\hline$\overbrace{1981-2001}$ & $\begin{array}{l}\text { SF homes in rural areas built from } \\
1981 \text { to } 2001 \text {, after the introduction } \\
\text { of Spain's first mandatory thermal } \\
\text { regulations. }\end{array}$ & $\begin{array}{l}\text { Built with cavity w } 1 / s \text { with integrated thermal } \\
\text { insulation, itched roof without air chamber, } \\
\text { outdoo ventiated crawl space under ground } \\
\text { floor. }\end{array}$ & $1,175,785$ \\
\hline \begin{tabular}{|c|}
$\mathrm{H}$ \\
\\
\\
$1981-2001$
\end{tabular} & $\begin{array}{l}\text { MF housing located in rural towns } \\
\text { and built between } 1981 \text { and } 2001 \text {. }\end{array}$ & $\begin{array}{l}\text { ilt with cavity walls with thermal insulation, } \\
\text { flat oofs and outdoor ventilated crawl space } \\
\text { under ground floor. }\end{array}$ & $1,381,041$ \\
\hline 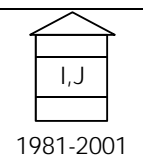 & $\begin{array}{l}\text { MF housing buildings in urban are as } \\
\text { built between } 1981 \text { and } 2001 .\end{array}$ & $\begin{array}{l}\text { Built with solid walls with insulation, flat roofs } \\
\text { and outdoor ventilated crawl space under } \\
\text { ground floor. }\end{array}$ & $2,400,337$ \\
\hline & & Total main dwellings built up to 2001 : & $15,358,608$ \\
\hline
\end{tabular}

\subsection{Climatic zones}

Some existing applications of the cost-optimal methodology in renovation projects, as for example the INSPIRE-Tool dovelop d by econcept AG for the Swiss context [70], do not take into account the different climatic 20 nes, making their application restricted to a specific region in the country. However, we aim to apply our pproach to the whole Spanish territory, so it is imperative to take into account the different climatic zones of Spain, mainly differentiated according to the winter (WCS) and summer (SCS) climate severity defined in the current regulation CTE $[7,18]$. Our proposal is to consider all 12 climatic zones present in the Iberian Peninsula, represented through the ombrothermic graphs in Figure 3 according to the location of the provincial capital [18]. 
A3 - Málaga

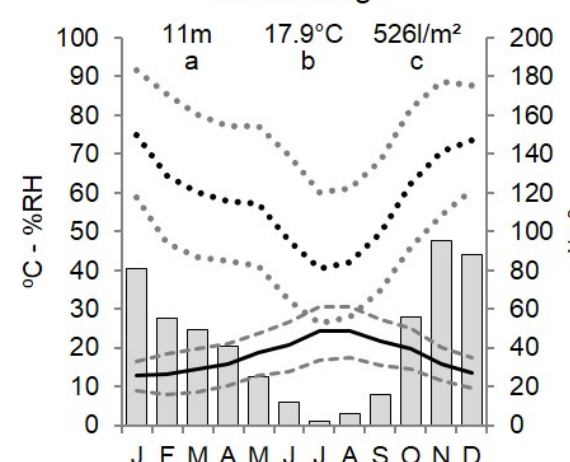

C1 - Coruña

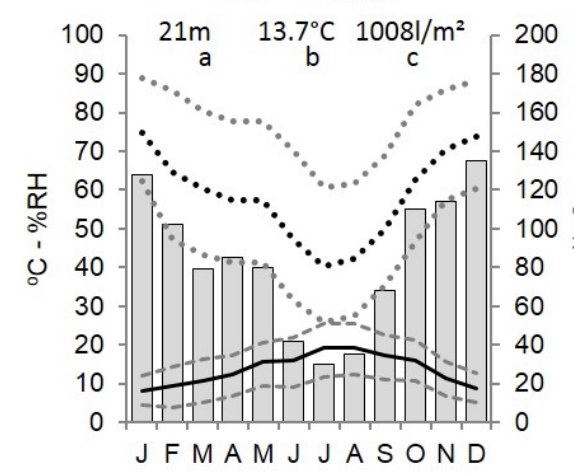

D1 - Lugo

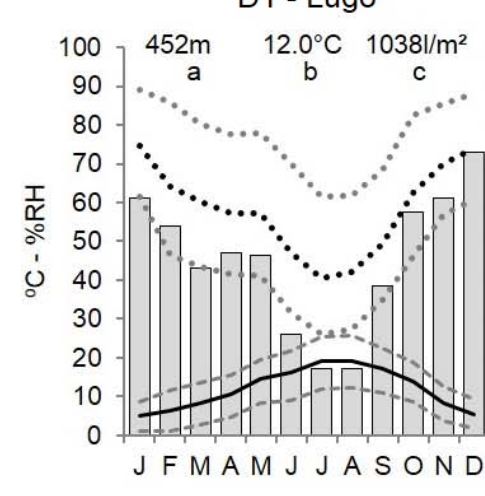

A4 - Almería

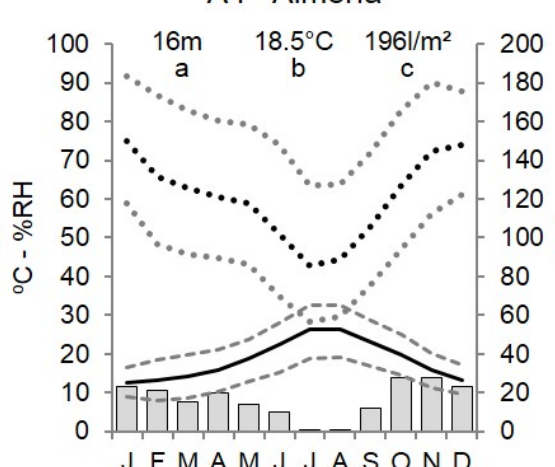

C2 - Barcelona

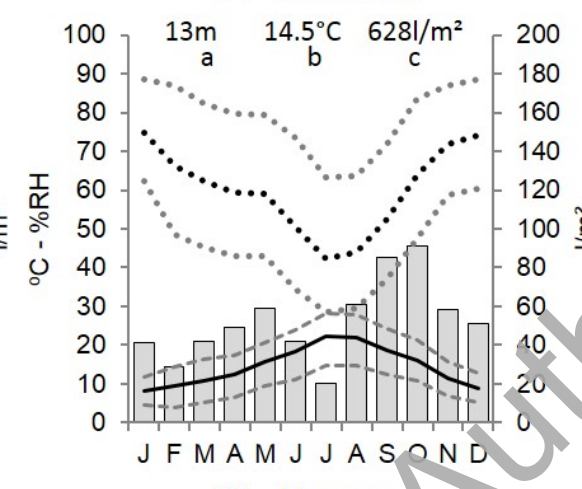

D2 - Huesca
B3 - Tarragona

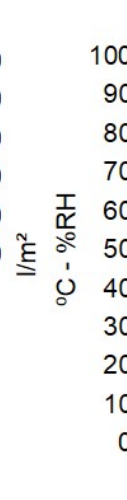

8m $\quad 17.0^{\circ} \mathrm{C} \quad 5311 / \mathrm{m}^{2} \quad 200$

$\left.\begin{array}{ccc}a & b & c\end{array}\right]\left[\begin{array}{cc}200 \\ 180\end{array}\right.$

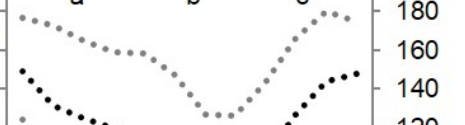

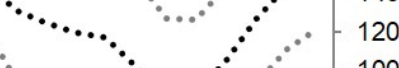

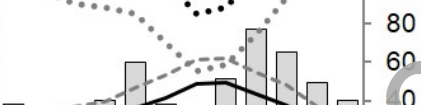

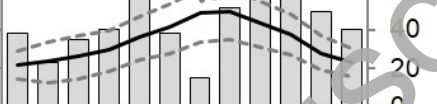

JFMAMJJA SO T 0

C3 - Granaca

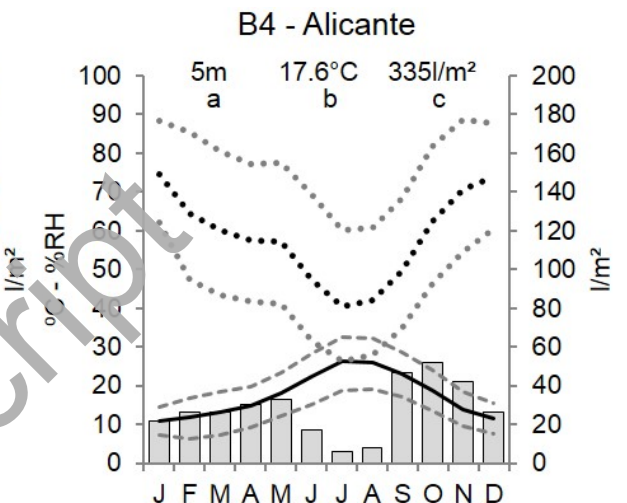

C4 - Cáceres
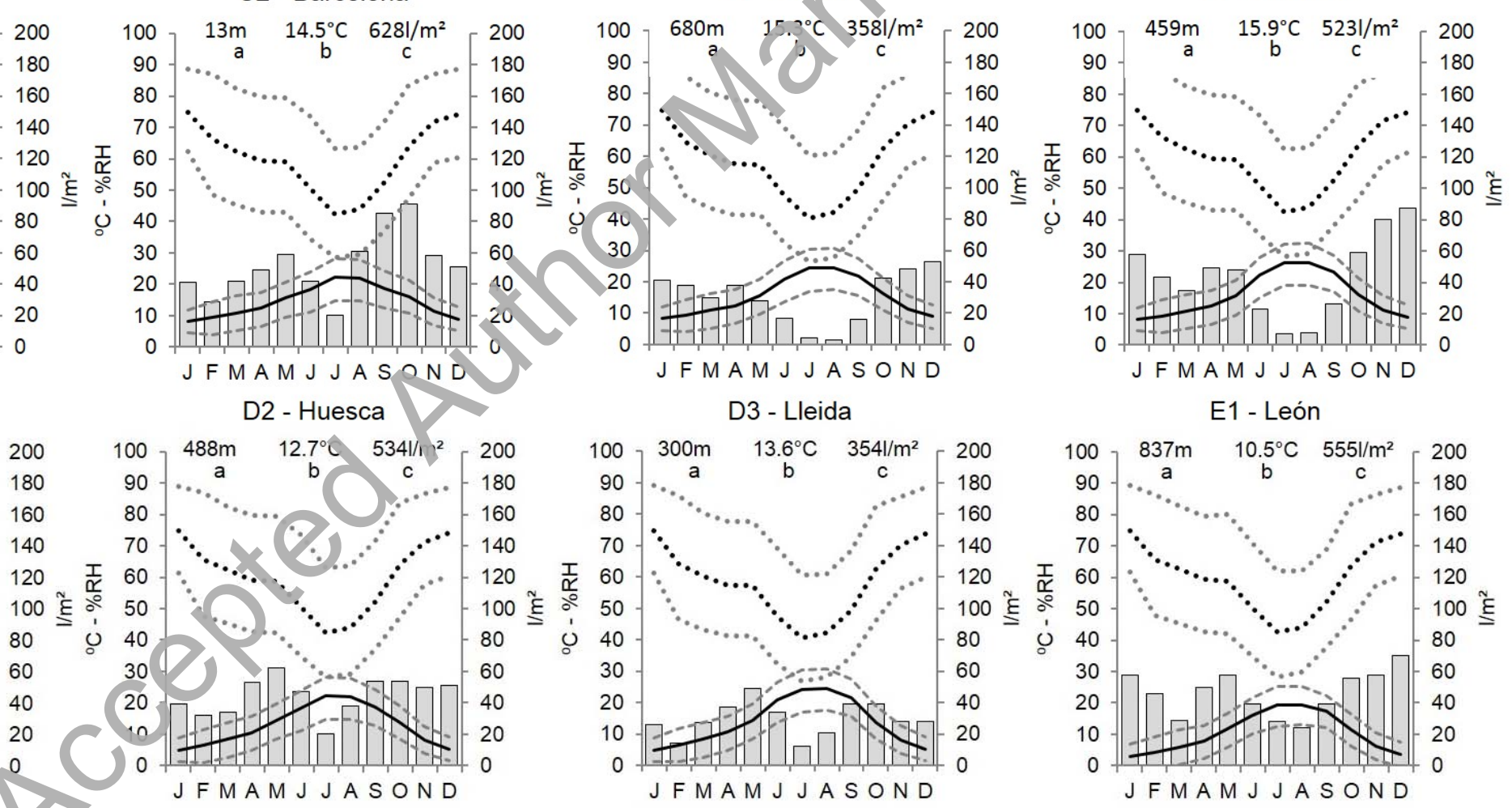

D3 - Lleida

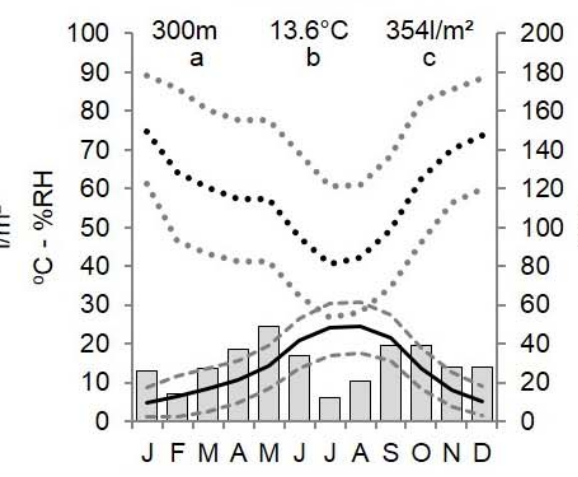

\section{E1 - León}

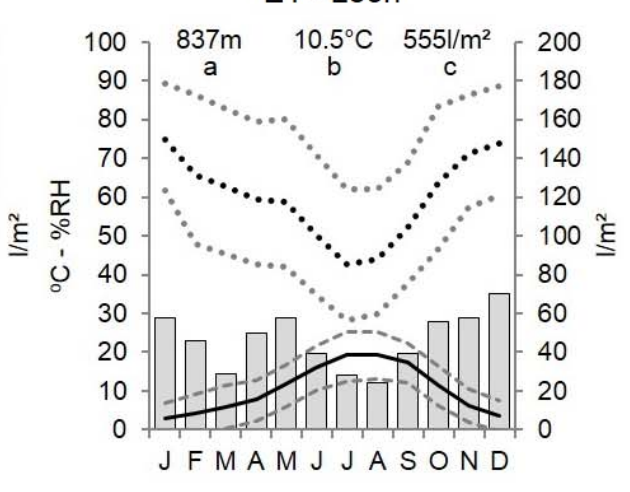

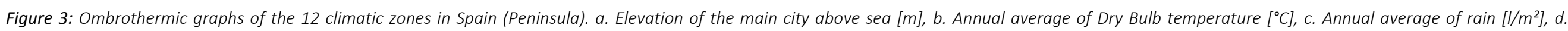

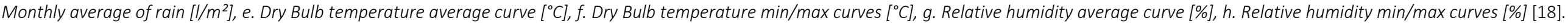




\subsection{Existing building envelope characteristics of each archetype}

To simulate the energy demand of each archetype, defined as a theoretical model for each typology, and scale-up the results at the territorial scale, we utilize the shape coefficients listed in Table 3. These values, taken from a study from the GTR [68] and the master thesis of the first author [36], correspond to the ratio between the surface of each constructive component - facade, windows, roof and ground floor - and the floor area (e.g. $\mathrm{m}^{2}$ of opaque facade $/ \mathrm{m}^{2}$ floor area).

Table 3: Shape coefficients by archetype [68].

\begin{tabular}{cccccc}
\hline \multirow{2}{*}{ Archetype } & \multicolumn{2}{c}{ Shape coefficients by archetype $\left[\mathrm{m}^{2}\right.$ of component $/ \mathrm{m}^{2}$ floor area] } & \multirow{2}{*}{ Floor area $\left[\mathrm{m}^{2}\right]$} & Storey height $[\mathrm{m}]$ \\
\cline { 2 - 5 } & Opaque facade & Windows & Roof & Ground floor & \\
\hline A & 0.87 & & 0.69 & 0.69 & 109 \\
B & 0.46 & & 0.18 & 0.18 & 85 \\
C & 0.87 & 0.14 & 0.69 & 0.69 & 109 \\
DEF & 0.46 & & 0.18 & 0.18 & 85 \\
G & 0.87 & & 0.69 & 0.69 & 109 \\
H & 0.62 & & 0.50 & 0.50 & 93 \\
IJ & 0.46 & 0.18 & 0.18 & 85 \\
\hline
\end{tabular}

We have obtained the envelope characteristics (U-value) for each archetype from the study of the Spanish residential building stock carried out by the GTR [68], updating an validating the values using the database of the official software (CE3X) for EPC in Spain [62]. An example ror a hetype DEF can be found in Table 4.

\subsection{Packages of energy-efficiency measures}

When considering interventions performed at diffent moments in the life of the building, it becomes crucial to simultaneously consider mixed solutions (active/passive). This is because the lifetime of the components is different, e.g. 15 years for a voller versus 50 years for thermal insulating elements. Likewise, the order of priority in the implemen tation of different renewal strategies (passive or active) is important to achieve a high value of long-ternnsaving in terms of energy, GHG emissions, and cost $[10-12,24,41]$. First, it is necessary to act on the building envelope to reduce the energy demand, and then install active systems adapted to the new deriand. In this sense, the evaluation of investments takes into account not only economic aspects but also environmental impacts associated with the life of the building. Before applying the cost-optimal methodology, we must be sure that each strategy is technically feasible, according to the character sti of the building. This is done by consulting the literature $[49,71-73]$ and defining our different rehabilitation strategies using the GTR report [65], introduced in section 3, as a basis.

\subsubsection{Packages of passive improvement strategies}

For our purpose of generating a pre-simulated database, we have chosen two packages of passive strategies, representing two levels of intervention (REFO1 and REF02), in addition to the current status (ORIG), in order to limit the number of combinations to simulate. These represent the options that can then be selected using our Excel-based decision-making tool, as further detailed in section 4.6. An example of the defined packages for archetype DEF, including building envelope features (simulation input data), cost, and environmental impact, is presented in Table 4. 
Table 4: Definition of improvement packages with the resulting envelope characteristics, cost of each strategy and their environmental impact, for a lifetime of 15 years (for LCA). The values corresponds to archetype DEF (see Table 2) [62,68,74].

\begin{tabular}{|c|c|c|c|c|}
\hline \multicolumn{5}{|c|}{ Mean U-value after rehabilitation $\left[\mathrm{W} / \mathrm{m}^{2} . \mathrm{K}\right]$ for archetype DEF } \\
\hline ORIG (Current status) & Facade & Windows & Roof & Ground slab floor \\
\hline Without improving building performance & 1.30 & 5.70 & 1.60 & 2.50 \\
\hline REF01 (Minor retrofit) & Facade & Windows & Roof & Ground slab floor \\
\hline Exterior insulation and ventilated facade & 0.22 & - & - & - \\
\hline Double-glazed window & - & 2.7 & - & - \\
\hline REF02 (Deep retrofit) & Facade & Windows & Roof & Ground slab floor \\
\hline Exterior insulation and ventilated facade & 0.22 & - & - & - \\
\hline Double-glazed window & - & 2.7 & - & - \\
\hline Roof insulation & - & - & 0.25 & \\
\hline Insulation of the ground floor & - & - & - & 0.25 \\
\hline \multicolumn{5}{|c|}{ Cost of strategies [ $€$ per $\mathrm{m}^{2}$ of element] } \\
\hline Improvement strategy & Facade & Windows & Roof & Ground slab floor \\
\hline Exterior insulation & $151 € / \mathrm{m}^{2}$ & - & - & \\
\hline Double-glazed window & - & $335 € / \mathrm{m}^{2}$ & - & \\
\hline Roof insulation & - & - & $46 € / \mathrm{m}^{2}$ & \\
\hline Insulation of the ground floor & - & - & - & $1 \mathrm{~m}^{2}$ \\
\hline Environmental impacts & \multicolumn{2}{|c|}{ Embodied energy [kWh/dwelling] } & \multicolumn{2}{|c|}{ GHG emissions [ $\left.\cdot \mathrm{CO}_{2} / \mathrm{dwelling}\right]$} \\
\hline REF01 (Minor retrofit) & \multicolumn{2}{|c|}{$14^{\prime} 449$} & \multicolumn{2}{|c|}{$2^{\prime} 046$} \\
\hline REF02 (Deep retrofit) & \multicolumn{2}{|c|}{$20^{\prime} 439$} & \multicolumn{2}{|c|}{2443} \\
\hline
\end{tabular}

\subsubsection{Active improvement strategies (HVAC system)}

For providing the user with different active systems to be impleme ted in the scenarios, we have considered the performance level of the most common HVAC systems usec renovation projects in Spain given by the CYPE database [74] (Table 5). These values are applied to the pre-simulated energy demand to obtain the final consumption result (see 4.6.).

Table 5: Definition of active improvement strategies through he performance of HVAC system and the type of energy consumed (gas, biomass and electricity-based), cost of each system and the. envivonmental impact, for a lifetime of 15 years (for LCA) [74].

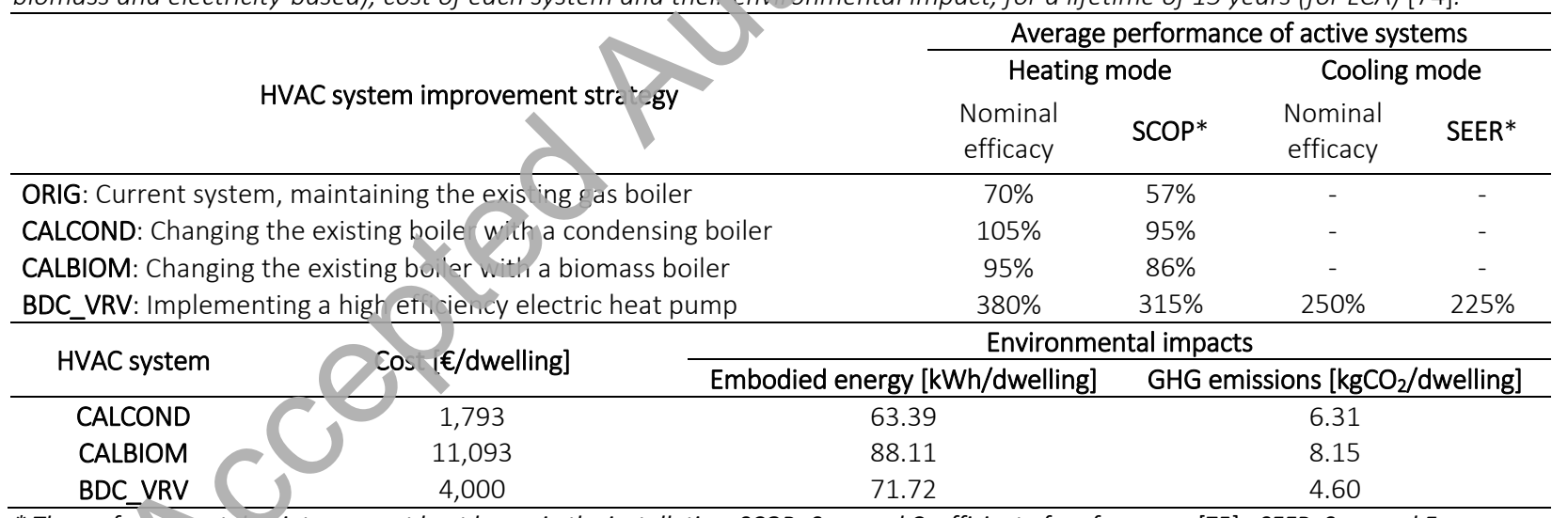

* The perfor anc takes into account heat losses in the installation. SCOP: Seasonal Coefficient of performance [75], SEER: Seasonal Energy Efficiency Rat, [6].

\subsubsection{Additional strategies}

To take into account the potential contribution of RET on buildings to achieve the nZEB standard [77], two complementary strategies have been defined. (1) RCALOR: mechanical ventilation system with heat recovery, taking into account the percentage of the energy demand reduced by implementing this system assuming 1 ach in winter and 5 ach in summer (Table 6). (2) SOLARACS: solar panels to cover $50 \%$ of annual DHW demand. Table 7 presents the values considered in terms of cost and environmental impact for these two additional strategies. 
Table 6: Percentage reduction in the energy demand when implementing RCALOR strategy (mechanical ventilation system with heat recovery with 1 ach in winter and 5 ach in summer). Values calculated from own simulations using technical system data from Soler\&Palau manufacturer [79].

\begin{tabular}{|c|c|c|c|c|c|c|c|c|c|c|c|c|}
\hline Climatic zone & $\mathrm{A} 3$ & A4 & B3 & B4 & $\mathrm{C} 1$ & $\mathrm{C} 2$ & $\mathrm{C} 3$ & $\mathrm{C} 4$ & D1 & D2 & D3 & E1 \\
\hline Heating & $18 \%$ & $14 \%$ & $21 \%$ & $20 \%$ & $29 \%$ & $27 \%$ & $23 \%$ & $21 \%$ & $31 \%$ & $30 \%$ & $28 \%$ & $33 \%$ \\
\hline Cooling & $9 \%$ & $6 \%$ & $20 \%$ & $13 \%$ & $0 \%$ & $8 \%$ & $4 \%$ & $12 \%$ & $0 \%$ & $13 \%$ & $16 \%$ & $0 \%$ \\
\hline
\end{tabular}

Table 7: Cost and environmental impacts (for LCA, considering a lifetime of 15 years) of additional strategies [75].

\begin{tabular}{cccc}
\hline \multirow{2}{*}{ Additional strategy } & \multirow{2}{*}{ Cost [€/dwelling] } & \multicolumn{2}{c}{ Environmental impacts } \\
\cline { 3 - 4 } & & Embodied energy [kWh/dwelling] & $\left.\mathrm{GHG} \mathrm{emissions} \mathrm{[kgCO}_{2} / \mathrm{dwelling}\right]$ \\
\hline RCALOR & 1,793 & 63.39 & 6.31 \\
SOLARACS & 11,093 & 88.11 & 8.15 \\
\hline
\end{tabular}

\subsection{Definition of nearly Zero Energy Buildings (nZEB) requirements}

The EPBD recast [17] proposes using the cost-optimal methodology to support nZEB desisn [8,33]. To verify whether or not the proposed renovation scenarios may allow achieving the EU targets for the 2020 and 2050 horizons using the nZEB concept as a measure, we must first define its meaning.

All EU Member States (MS) should set the nZEB targets [17] - reflectin, then national, regional or local conditions - through a numerical indicator of maximum PE consumption expressed in $\mathrm{kWh} / \mathrm{m}^{2}$ per year, but the literature review about this subject shows that there is ro consensus to define the energy efficiency targets of a nZEB [16].

As for the moment the Spanish regulation presents a lov er level of exigency, in terms of energy efficiency in building renovation [18], than the last Europear directive [17] and also compared to the limits of PE and GHG emissions imposed by the standards of neigh houring EU countries like Germany or France [16].

Some recent publications about the defin Ion of nZEB across EU countries $[16,78]$ show that only nine EU countries have formally established $n Z \mathrm{E} B$ requirements for existing residential buildings ranging between 20$200 \mathrm{kWh} / \mathrm{m}^{2}$ per year (of PE cor s mption) and only six of them use the same requirements for both new and existing buildings (20-100 $\mathrm{kW} / \mathrm{m}^{2}$ per year of PE consumption). Spanish regulations are still under development.

Given this information and following the recommendations of some publications $[10,50]$, the use of the German Pas whaus label [79] as a reference to define nZEB requirement is here considered as a reasonable approach [0]. The target values taken into account are presented in Table 8.

Table 8: Energy efficiency requirements for nZEB standard, according to the German Passivhaus label [79].

\begin{tabular}{lcc}
\hline \multicolumn{1}{c}{ Requirement } & Heating & Cooling \\
\hline Maximum energy demand [kWh/m² per year] & 15 & 15 \\
\cline { 2 - 2 } Maximum PE consumption (Including heating, cooling and DHW) $\left[\mathrm{kWh} / \mathrm{m}^{2}\right.$ per year] & 120 \\
Minimum Energy Performance Certification rate (according to Spanish EPC protocol [20]) & $\mathrm{B}$ \\
\hline
\end{tabular}

Trying to go a little further, a reference publication about principles for nZEB by the Building Performance Institute Europe (BPIE) highlights a lack of implementation of the LCA approach for nZEB within the costoptimal methodology [23]. Hernandez et al. [81] propose a new-term: life-cycle zero-energy buildings (LCZEB), integrating the embodied energy related to the life cycle of buildings. 
In response to this, we propose to implement the Life-Cycle Assessment (LCA) and Life-Cycle Cost (LCC) into the assessment and our Excel-based tool, to have an overview and identify the possible improvements regarding the renovation strategies proposed, allowing us to check if it is possible to achieve the ambitious EU horizon 2050 objectives of $3 \mathrm{kgCO}_{2} / \mathrm{m}^{2}$ per year (over the whole life cycle).

\subsection{Estimation of energy performance improvements}

\subsubsection{Calculation horizon}

For the economic and energy consumption calculation throughout the life of the building, the following horizons have been defined: 2020, 2030 and 2050 (short, medium and long term). A comparison between a reference case (no improvement actions) and four scenarios with the application of different imporement strategies are presented.

\subsubsection{Outputs}

The main outputs from our multi-criteria evaluation are:

- Global cost, taking into account initial investment, maintenance cost, sub titution cost of the current HVAC systems, and energy consumption cost;

- Net Present Value (NPV) and Payback Period (PBP), using saviris sos a cash-flow to recover the investment; - Primary energy (PE) consumption and related GHG emissio is;

- Cumulative cost of energy consumption and saving depend $\mathrm{ng}$ on the horizon of calculation (for LCC);

- Embodied energy and related emissions taking into account materials and energy use (for LCA).

\subsection{Decision-making tool in the Excel en vironment}

In this section we briefly describe the work Flow (Figure 5) implemented into an Excel-based decision-making tool. The main objective of this too is to enable the comparison of different renovation scenarios in terms of the above-mentioned outpus, irough graphical representations of the results. The two main screens of the tool are presented in Figu es and 7.

As shown in Figure 4, the tool first needs (1) the definition of scenarios by the user (in terms of passive, active and RET strat gies) and the type of study desired (scale; for only one versus all archetype(s) and climatic zone(s)). Uscrs can then, through the (2) user-friendly interface (Figures 6 and 7), define the macroeconomic parameters (energy price evolution, interest rate and percentage of subsidies) and the calculation horizon (2020, 2030 or 2050). Based on this information, the corresponding data is extracted from (3) the toolintegrated database, including the energy demand of each archetype from the pre-simulated data (see Figure 6). The data is then passed on to (4) a calculation algorithm based on the cost-optimal methodology (Figure 2). We obtain the results according to the chosen scenario (combination of passive, active and RET strategies - including the moment of implementation) (5a) for a specific archetype and climatic zone if the user has chosen the static calculation option. If (5b) the user has chosen the territorial scale overview, an automatic iterative process scales-up the individual results to the territorial scale using the statistical data integrated in 
the Excel tool. At each iteration, for a given retrofitting scenario, the archetype and climatic zone are varied. Finally, this process ends up storing all results in a double entrance table (archetype vs climatic zone, see examples in section 5.3).

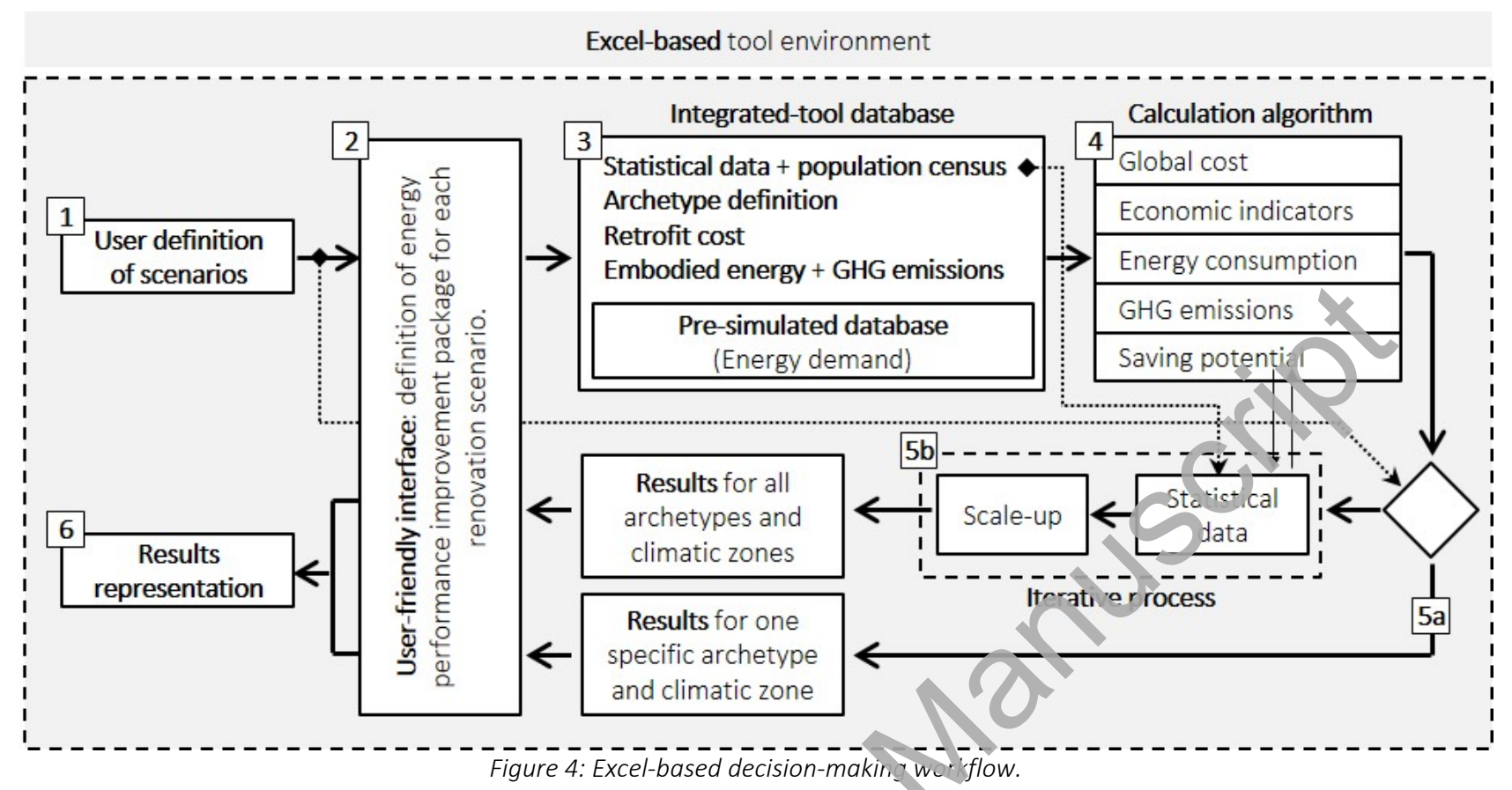

The tool-integrated database which feeds the calculation algorithm is composed of:

Census of population and statistical building const uction data: mean surface of each typology and number of homes of each type for each climatic zone [1, 14].

Archetype parametrization: based on surface ratios as explained in section 4.3.

Cost of each retrofit measure: invos ment cost [74], maintenance, substitution, and rate of efficiency loss of HVAC systems over the years 156,02$]$.

Embodied energy and GHG em issions associated to the materials used in each scenario [74].

Pre-simulated energy emand database: as shown in Figure 6, the generation of the pre-simulated database starts with (1) the anchetype parametrization (section 4.3) and (2) the assignment of three scenarios for each archetype (s ction 4.4). This information is introduced (3) into the simulation tool environment, currently the CE3X software since we are working at a macro scale. However, for more accurate simulations, EnergyPlus could be used, as done in section 5.1 to test the accuracy of our results. (4) Finally, we obtain the results in .xml files (from CE3x) and .csv (from EnergyPlus). (5) These form the database of energy demand for heating, cooling, and DHW integrated into our Excel tool. 


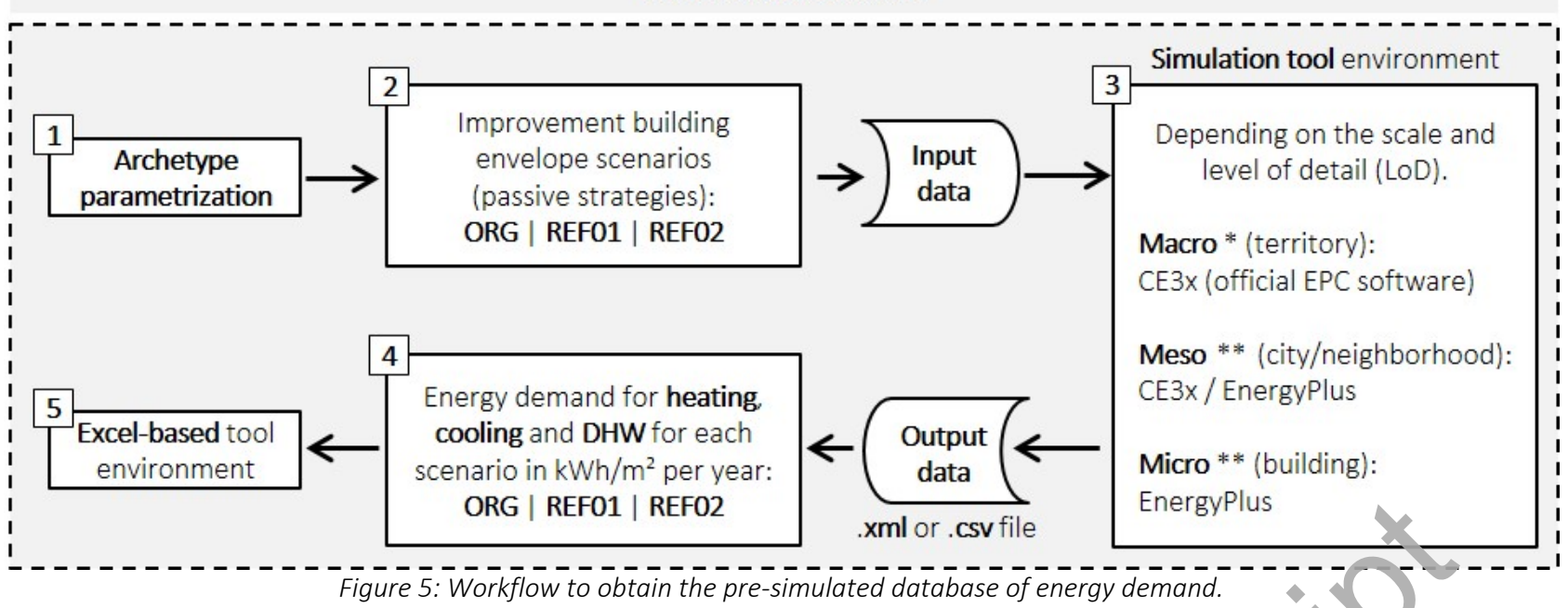

Obtaining this pre-simulated database involves some simplifications and hypotheses that will determine the level of accuracy of the final results, and which are related to the level of detail (LOD) of the energy model. In this case, we have modelled our seven theoretical archetypes (Table 2) basec on shape coefficients defined by the surface ratio of each constructive component (Table 5), taking into ccount two exposed facades with opposite orientation, and simulating each model in four orien tions to obtain a mean value of the energy demand.

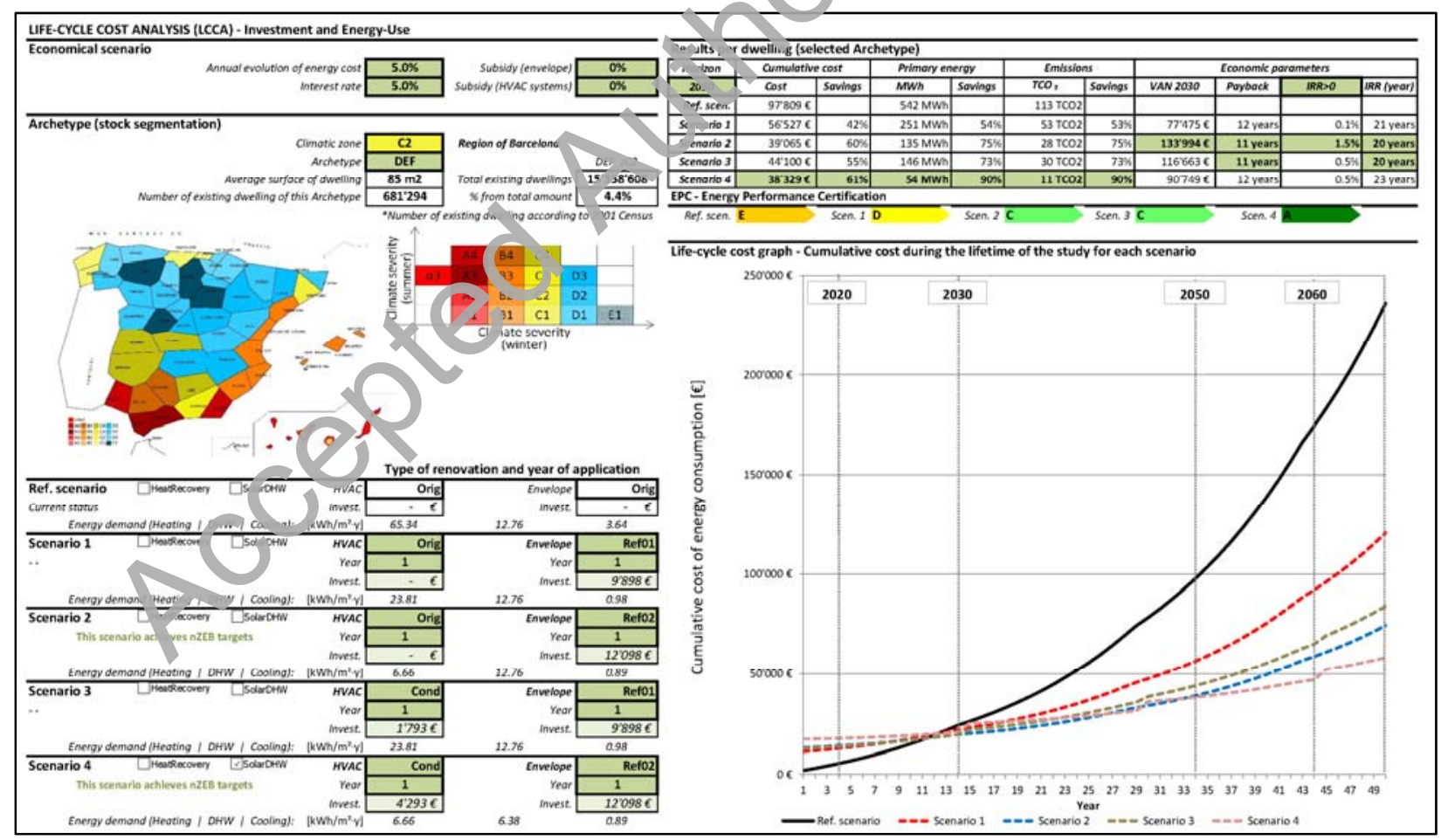

Figure 6: Decision-making tool - Main window of the LCC - Investment and energy-use for different calculation horizons. 


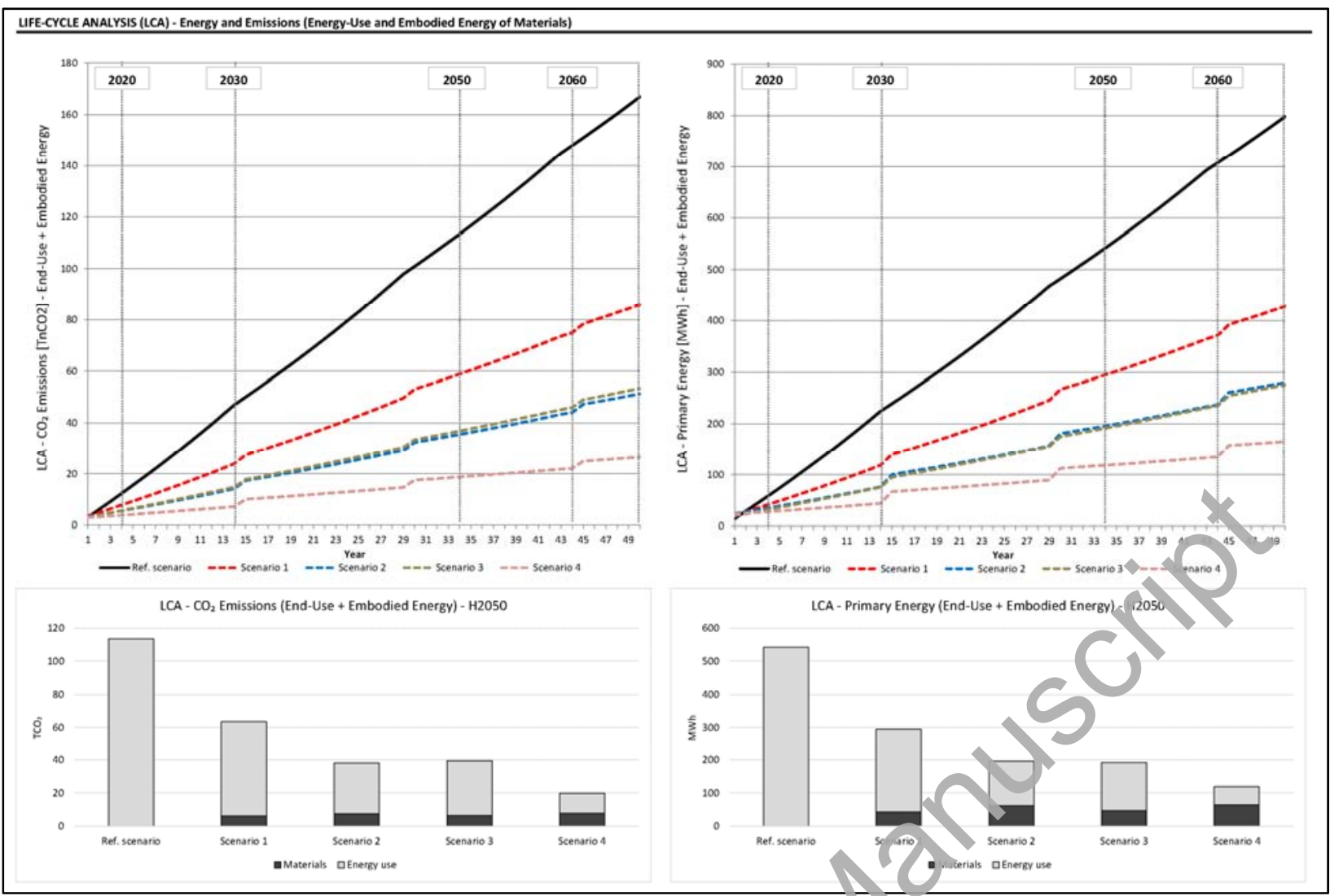

Figure 7: Decision-making tool - Main window of the LCA - Energy and emissio inc'uaing end-use and embodied energy for different calculation horizons.

\section{Results}

In this section, we first present the results from accuracy test to quantify the error associated to the archetype-based approach (using the CE3x tool) compared to dynamically simulating with EnergyPlus a real building corresponding to the same archety, The subsequent sections 5.2 and 5.3 respectively illustrate the types of studies that can be cona cted at the building and territorial scales, including the examples listed in section 3.

\subsection{Accuracy test}

At a territorial scale, tis ho possible to know exactly how is the surrounding environment, particularly to take into account olzr obstructions when calculating the level of solar irradiation on each building surface. Consequentwy energy simulations have been run in different orientations and the average of the results is used. To es imate the error caused by assuming this hypothesis, a detailed case study was performed of over 400 dwellings of archetype DEF (4-storey MF buildings) in the urban development of La Roureda - a representative neighbourhood from the 70's located in Sabadell (Barcelona) (Figure 8). This archetype was selected as it is the most widespread according to the statistical data analysed $[7,13,14,65]$ (Table 2$)$. 


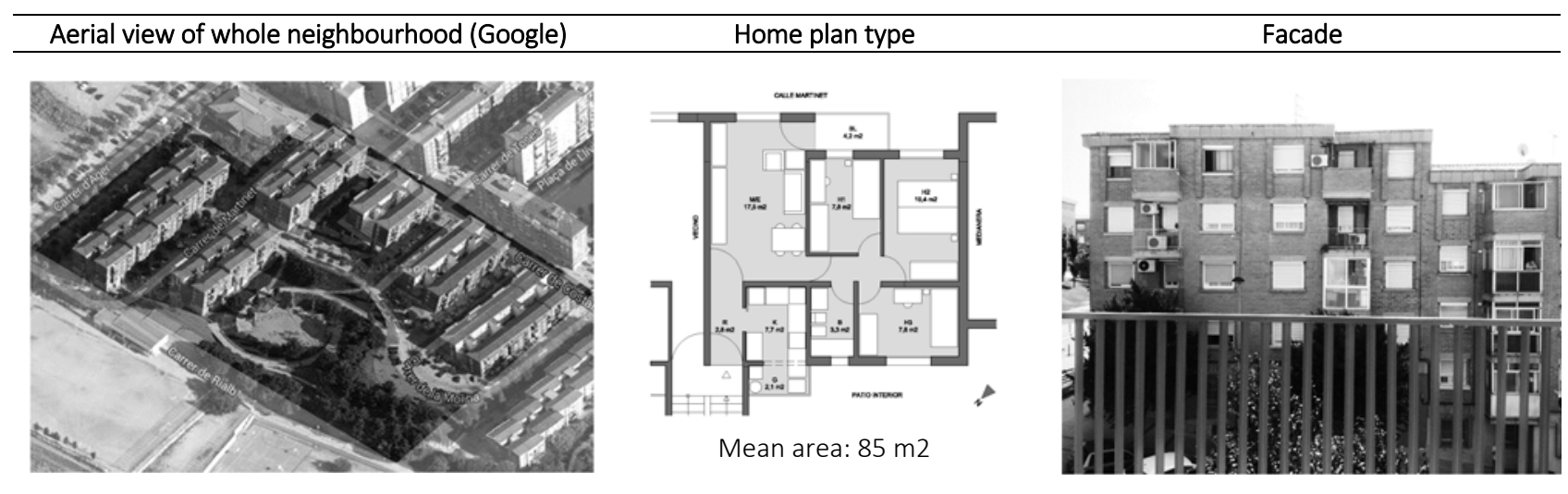

Figure 8: Definition of La Roureda Neighbourhood - Sabadell (Barcelona).

The main idea is to increase the LoD thanks to the higher precision of input parameters (from the construction and built environment point of view) to make a more accurate energy simulation using the DesignBuilder software based on the EnergyPlus calculation engine. This process aliows verifying the reliability of the results, presented in Table 9, before applying the methodology ara rorge scale. The mean error of $25 \%$ is considered as acceptable for the purpose of application (estimation ol potential savings) and given the error authorized in other studies [70].

Table 9: Comparison of CE3x and EnergyPlus simulation results.

\begin{tabular}{|c|c|c|c|}
\hline Indicator & CE3X & Escrayilus & Estimation error \\
\hline Heating demand & $65.34 \mathrm{kWh} / \mathrm{m}^{2}$.year & $55.25 \mathrm{k} / \mathrm{h} / \mathrm{m}^{2}$ year & $+15 \%$ \\
\hline Cooling demand & $3.64 \mathrm{kWh} / \mathrm{m}^{2}$.year & $10.41 \mathrm{kWh} / \mathrm{m}^{2} \cdot$ year & $-35 \%$ \\
\hline
\end{tabular}

\subsection{Results at the building scale}

Using the same archetype as in section 5 1, four renovation scenarios (S1, S2, S3 and S4) described in Table 10 were tested. This section shows at example of the results at the building scale (Figure 9, 10a, 10b).

From the cost-optimal chart of -ig are 9, the four scenarios can be compared in terms of global cost, primary energy consumption, and cost effectiveness of each strategy. For the considered horizon of 2050, S2 - with a positive NPV - is the so -optimal solution, despite the fact that it is not the scenario with the lowest consumption. Cor paring between S1 and S2, we observe that although they have similar global costs, S1 has a PE almost do uble that of $\mathrm{S} 2$, and a low NPV.

Figure 10a, illustrating the LCC though the accumulated energy consumption costs, allows comparing the same scenarios in terms of savings according to the different calculation horizons. In this case, we observe that the S1-S4 curves fall below the initial scenario (SO) after 11-13 years, therefore corresponding to the simple payback time (SBPB). This means that S1-S4 are all cost-effective in a long-term horizon (2050). 


\begin{tabular}{ccc}
\hline Scenario & Passive strategies & Active strategies \\
\hline SO & ORIG & ORIG \\
S1 & REF01 & ORIG \\
S2 & REF02 & ORIG \\
S3 & REF01 & CALCOND + RCALOR + SOLARACS \\
S4 & REF02 & CALCOND + RCALOR + SOLARACS \\
\hline
\end{tabular}

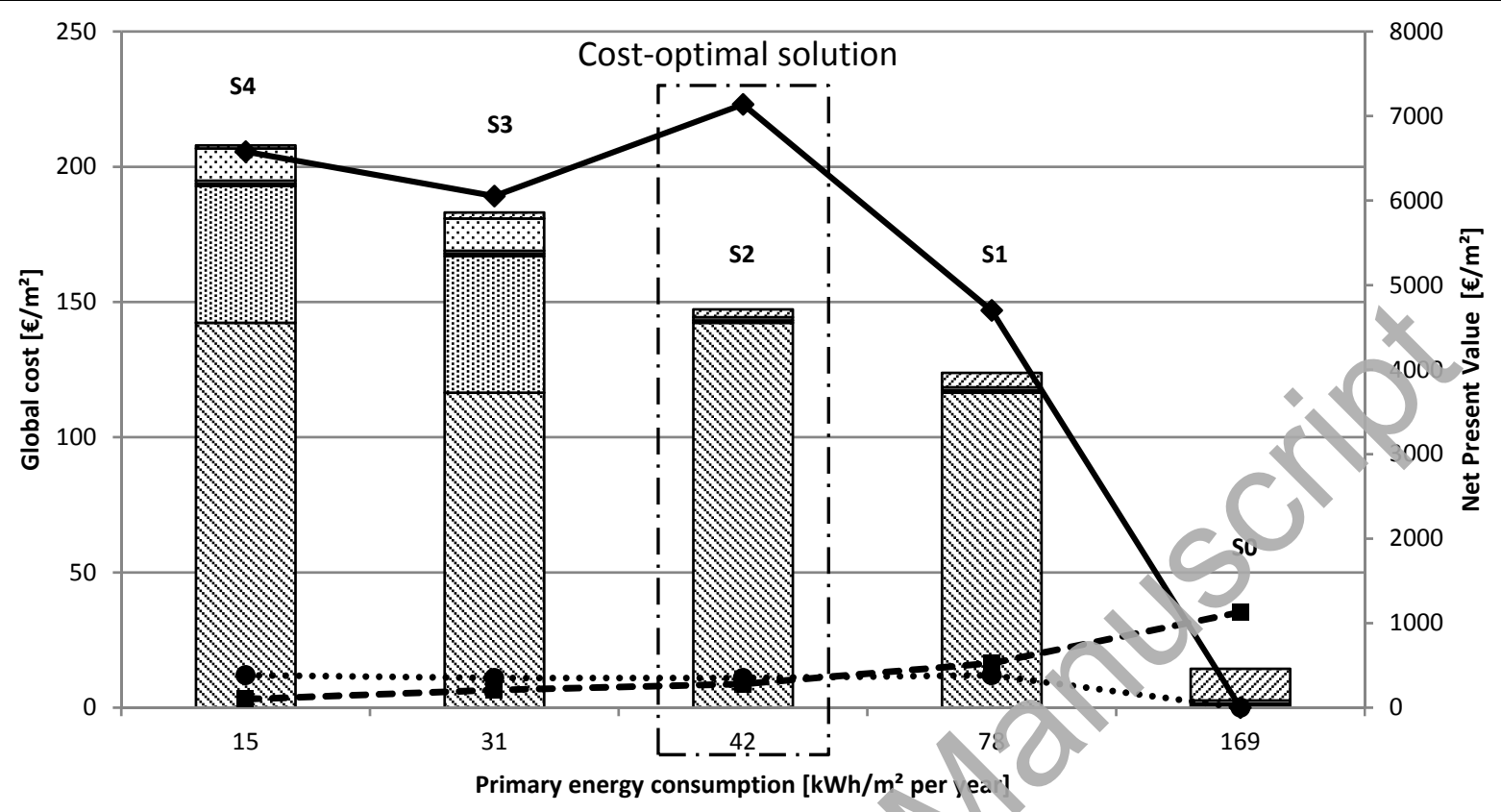

$\$ \$$ Envelope investment $\left[€ / \mathrm{m}^{2}\right]$ $\square$ Other costs $\left[€ / \mathrm{m}^{2}\right]$

...... Simple Payback Period [years]
[B]

HVAC systems elimina on cost $\left[€ / \mathrm{m}^{2}\right]$

- - GHG emissions [' $\mathrm{gCO}$ / $\mathrm{m}$ ]
Maintenance cost $\left[€ / \mathrm{m}^{2}\right]$

CWCCA Energy consumption cost $\left[€ / \mathrm{m}^{2}\right]$

Net Present Value $\left[€ / \mathrm{m}^{2}\right]$

Figure 9: Cost-optimal chart for DEF archetype if the cimatic zone C2-Barcelona, for a 2030 horizon.

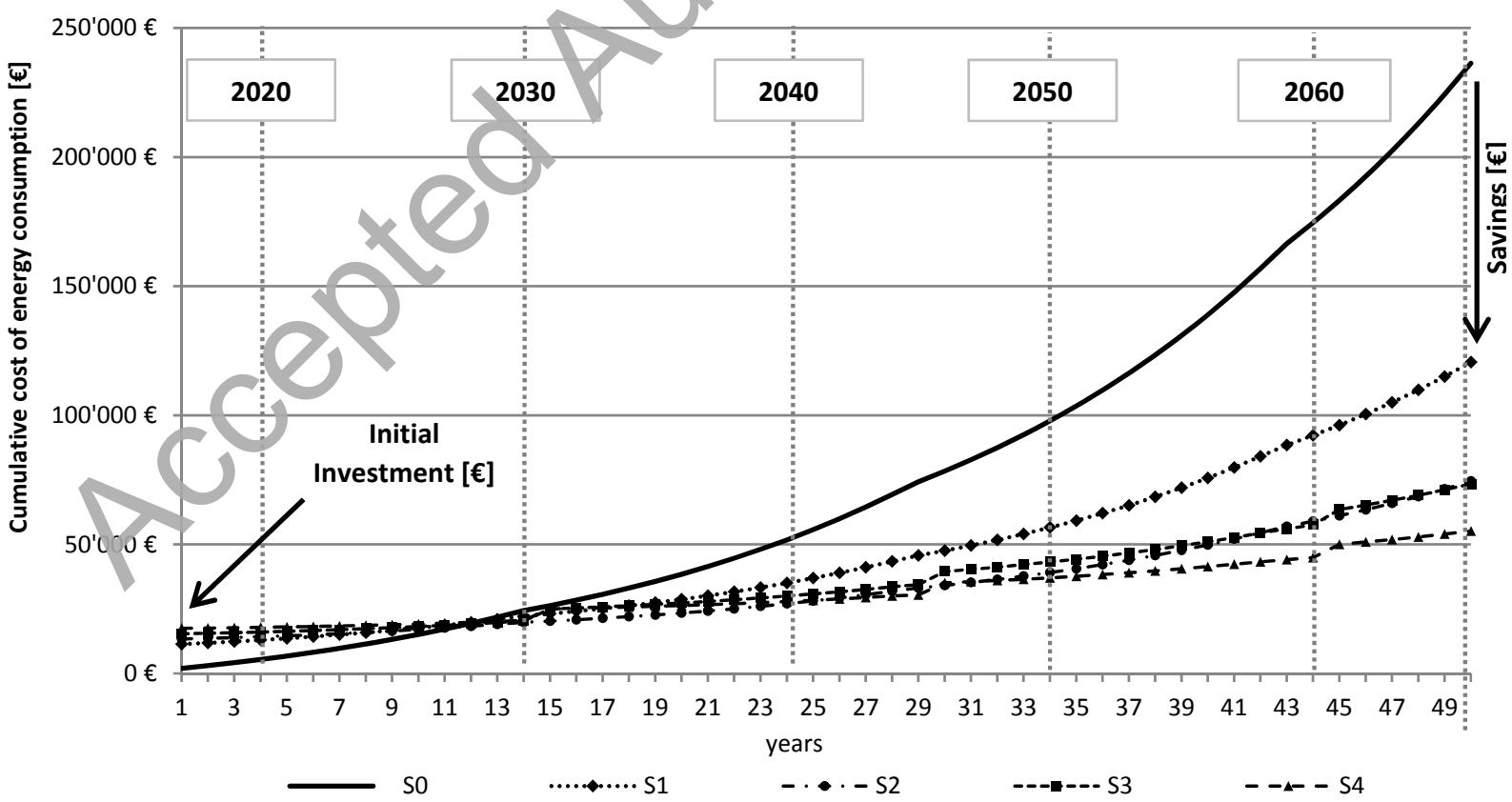

Figure 10a: Life-Cycle Cost (LCC) per dwelling. See Table 10 for description of scenarios.

Figure $10 \mathrm{~b}$ shows the results of the LCA of each scenario in terms of embodied energy and GHG emissions. 


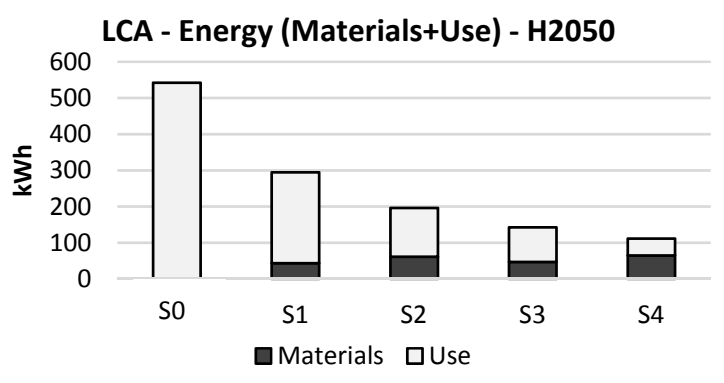

LCA - Emissions (Materials+Use) - H2050

Figure 10b: Life-Cycle Analysis (LCA) per dwelling. See Table 10 for description of scenarios.

\subsection{Scaling-up of results at the territorial scale}

In this section, five examples of results at the territorial scale are presented. Through he bottom-up approach described in section 4.7 to obtain the results for the whole building stock, a simu ltaneous overview of the seven building archetypes and 12 climatic zones is provided.

\subsubsection{Cost-effectiveness between active and passive strategies}

In this section, the implementation of an active strategy (acting on HVAC sy tems) versus a passive strategy (acting on building envelope) is compared for a short- and long-term cuculation (Table 11b, 11c), using a $0.5 \%$ interest rate, $5 \%$ annual rate of increased energy costs and rour scenarios defined in Table 11 a.

Table 11a: Legend and description of considered scenarios according o the energy-efficiency measures presented in section 4.4

\begin{tabular}{ccc}
\hline Scenario & Passive strategies & Active strategies \\
\hline SC1 & ORIG & CALCOND \\
SC2 & ORIG & CALBIOM \\
SC3 & ORIG & BDC_VRV \\
SC4 & REFO2 & RCALOR + SOLARACS \\
\hline
\end{tabular}

Table 11b: The most cost-effective strategy recomm ended (for a short-term horizon of calculation). Cells marked with (-) represent cases that are not cost-effective before the alc lation horizon.

\begin{tabular}{|c|c|c|c|c|c|c|c|c|c|c|c|c|c|}
\hline \multirow{2}{*}{\multicolumn{2}{|c|}{ Horizon 2020}} & \multicolumn{12}{|c|}{ Climatic Zone } \\
\hline & & A4 & & B4 & B3 & $\mathrm{C} 4$ & $\mathrm{C3}$ & $\mathrm{C} 2$ & $\mathrm{C} 1$ & D3 & $\mathrm{D} 2$ & D1 & E1 \\
\hline \multirow{7}{*}{ 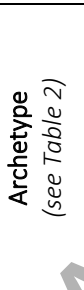 } & $A$ & SC1 & .1 & $\mathrm{SC} 3$ & SC1 & $\mathrm{SC} 3$ & $\mathrm{SC} 3$ & SC1 & SC1 & $\mathrm{SC} 3$ & $\mathrm{SC} 3$ & $\mathrm{SC} 3$ & $\mathrm{SC3}$ \\
\hline & B & & - & - & - & $\mathrm{SC} 3$ & SC1 & $\mathrm{SC} 1$ & SC1 & $\mathrm{SC} 3$ & SC3 & $\mathrm{SC} 3$ & SC3 \\
\hline & c & $\mathrm{sen}^{-1}$ & SC1 & SC1 & SC1 & $\mathrm{sc} 3$ & SC1 & SC1 & SC1 & SC1 & $\mathrm{SC} 3$ & $\mathrm{SC} 3$ & SC3 \\
\hline & DEF & & - & - & - & $\mathrm{SC} 3$ & $\mathrm{SC} 1$ & - & SC1 & SC1 & SC3 & $\mathrm{SC} 1$ & SC3 \\
\hline & G & SC1 & - & SC1 & SC1 & $\mathrm{SC} 3$ & SC1 & SC1 & SC1 & SC1 & SC3 & $\mathrm{SC} 3$ & SC3 \\
\hline & & - & - & - & SC1 & $\mathrm{SC} 3$ & $\mathrm{SC} 3$ & SC1 & $\mathrm{SC} 1$ & $\mathrm{SC} 3$ & SC3 & $\mathrm{SC} 3$ & SC3 \\
\hline & & - & - & - & - & $\mathrm{SC} 3$ & - & - & $\mathrm{SC} 1$ & SC1 & SC1 & $\mathrm{SC} 1$ & $\mathrm{SC} 3$ \\
\hline
\end{tabular}

Table 11c: Th most cost-effective strategy recommended (for a long-term horizon of calculation).

\begin{tabular}{|c|c|c|c|c|c|c|c|c|c|c|c|c|c|}
\hline \multirow{2}{*}{\multicolumn{2}{|c|}{ Horizon 2050}} & \multicolumn{12}{|c|}{ Climatic Zone } \\
\hline & & A4 & A3 & B4 & B3 & C4 & C3 & $\mathrm{C} 2$ & $\mathrm{C} 1$ & D3 & D2 & D1 & E1 \\
\hline \multirow{7}{*}{ 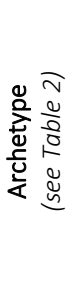 } & A & $\mathrm{SC} 3$ & SC3 & $\mathrm{SC} 3$ & SC3 & SC4 & SC4 & SC4 & SC4 & SC4 & SC4 & SC4 & SC4 \\
\hline & B & $\mathrm{SC} 3$ & SC3 & $\mathrm{SC} 3$ & SC3 & SC4 & SC4 & SC4 & SC4 & SC4 & SC4 & SC4 & SC4 \\
\hline & c & $\mathrm{SC} 3$ & $\mathrm{SC} 3$ & $\mathrm{SC} 3$ & SC3 & SC4 & SC4 & $\mathrm{SC} 3$ & SC4 & SC4 & SC4 & $\mathrm{SC} 4$ & SC4 \\
\hline & DEF & $\mathrm{SC} 3$ & SC3 & $\mathrm{SC} 3$ & SC3 & $\mathrm{SC} 3$ & SC4 & SC3 & SC3 & SC4 & SC4 & SC4 & SC4 \\
\hline & G & $\mathrm{sC} 3$ & SC3 & $\mathrm{SC} 3$ & SC3 & $\mathrm{SC} 3$ & $\mathrm{SC} 3$ & $\mathrm{SC} 3$ & SC3 & SC4 & SC4 & SC4 & SC4 \\
\hline & H & $\mathrm{SC} 3$ & SC3 & $\mathrm{SC} 3$ & SC3 & $\mathrm{SC} 3$ & $\mathrm{SC} 3$ & SC3 & SC3 & SC4 & SC4 & SC4 & SC4 \\
\hline & IJ & SC3 & SC3 & SC3 & SC3 & SC3 & SC3 & SC3 & SC3 & SC3 & SC3 & SC3 & SC4 \\
\hline
\end{tabular}

Results strongly depend on the horizon of calculation. When the calculation is carried out in the short term (Table 11b), the recommended strategy is the replacement of old heating systems (active). However, when 
the calculation is carried out in the long-term (Table 11c) the recommended strategy is a deep retrofit (passive), acting mainly on the building envelope. Therefore, the results show that the cost-optimal methodology is a tool that prioritizes deep retrofitting strategies in less efficient buildings (archetypes $A$ and B), located in the coldest regions such as D3, D2, D1 and E1 (see Figure 3).

\subsubsection{Relevance of active measures within passive strategies}

This section presents the comparison between implementing different passive strategies (REF01-minor or REF02-deep retrofit) with or without improving HVAC systems, for a mid-term horizon (2030), using a 0.5\% interest, 5\% annual rate of increased energy costs and five renovation scenarios, defined in Table 12a.

Table 12a: Legend and description of considered scenarios according to the energy-efficiency measures presented in sectio. 1.4 .

\begin{tabular}{ccc}
\hline Scenario & Passive strategies & Active strategies \\
\hline SC1 & REFO1 & ORIG \\
SC2 & REFO2 & ORIG \\
SC3 & REFO1 & CALCOND \\
SC4 & REF02 & CALCONID \\
\hline
\end{tabular}

Table 12b. The most cost-effective strategy recommended (for a mid-term horizon of calculation). cells marked with (-) represent cases that are not cost-effective before the calculation horizon.

\begin{tabular}{|c|c|c|c|c|c|c|c|c|c|c|c|c|c|}
\hline \multicolumn{2}{|c|}{ Horizon 2030} & $\mathrm{~A} 4$ & A3 & B4 & B3 & C4 & C3 & & -1 & D3 & D2 & D1 & E1 \\
\hline \multirow{7}{*}{ 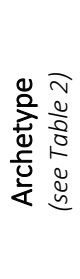 } & $A$ & - & - & - & - & $\mathrm{SC} 3$ & SC3 & $5: 2$ & $\mathrm{SC} 2$ & SC4 & SC4 & SC4 & $\mathrm{SC} 4$ \\
\hline & B & - & - & - & - & $\mathrm{SC} 4$ & SC2 & ses & $\mathrm{SC} 4$ & $\mathrm{SC} 4$ & $\mathrm{SC} 4$ & $\mathrm{SC} 2$ & $\mathrm{SC} 4$ \\
\hline & $C$ & - & - & - & - & $\mathrm{SC} 3$ & & $-\mathrm{C} 2$ & $\mathrm{SC} 2$ & $\mathrm{SC} 4$ & $\mathrm{SC} 4$ & $\mathrm{SC} 3$ & $\mathrm{SC} 4$ \\
\hline & DEF & - & - & - & - & $\mathrm{SC} 4$ & & SC2 & $\mathrm{SC} 2$ & $\mathrm{SC} 4$ & $\mathrm{SC} 4$ & $\mathrm{SC} 2$ & $\mathrm{SC} 4$ \\
\hline & G & - & - & - & - & - & & - & SC4 & $\mathrm{SC} 4$ & $\mathrm{SC} 4$ & $\mathrm{SC} 4$ & $\mathrm{SC} 4$ \\
\hline & $\mathrm{H}$ & - & - & - & - & & & SC2 & $\mathrm{SC} 2$ & SC4 & SC4 & $\mathrm{SC} 4$ & SC4 \\
\hline & IJ & - & - & - & - & & - & $\mathrm{sC2}$ & $\mathrm{SC} 2$ & SC4 & SC4 & $\mathrm{SC} 2$ & SC4 \\
\hline
\end{tabular}

The main conclusion that we can draw by xtr polating from this mid-term analysis, is that when the calculation is carried out in the short-term no passive strategy is economically viable. So, the recommended strategy is therefore the replacement of old heating systems (active). However, when calculated mid- or long-term (as indicated by the Elropean directives), the recommended strategy is a deep retrofit (passive strategies), acting mainly on cuchitectural components, as shown in Table 12b, with the exception of archetypes built in $\mathrm{Var}$ _ nes (A4, A3, B4, B3). In those cases, savings achieved implementing a deep retrofit do not jus ify the initial investment.

If the fixe a horizon is mid- or long-term (2030-2050), the building envelope retrofit strategy (REF02) is costeffective in $52 \%$ of the building stock, in the most climatic zones, starting with the most inefficient archetypes and coldest zones (Table 12b).

\subsubsection{Potential in achieving the nZEB target}

This section aims at verifying which archetype(s) of existing buildings could become nZEB, by applying a deep retrofit (REF02) and taking into account the different climatic zones (Table 13a). 
Table 13a: Buildings that could reach the level of performance for nZEB, through a deep retrofit REFO2 strategy. Cells marked with (-) represent cases that do not achieve the $n Z E B$ targets defined in section 4.5 .

\begin{tabular}{|c|c|c|c|c|c|c|c|c|c|c|c|c|c|}
\hline & & \multicolumn{12}{|c|}{ Climatic Zone } \\
\hline & & A4 & A3 & B4 & B3 & $\mathrm{C} 4$ & $\mathrm{C} 3$ & $\mathrm{C} 2$ & $\mathrm{C} 1$ & D3 & $\mathrm{D} 2$ & D1 & E1 \\
\hline \multirow{7}{*}{ 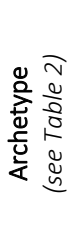 } & $A$ & nZEB & nZEB & nZEB & $n Z E B$ & - & - & - & - & - & - & - & - \\
\hline & B & nZEB & nZEB & nZEB & nZEB & - & nZEB & nZEB & nZEB & - & - & - & - \\
\hline & C & nZEB & nZEB & nZEB & $n Z E B$ & - & - & - & - & - & - & - & - \\
\hline & DEF & nZEB & nZEB & nZEB & nZEB & - & nZEB & nZEB & nZEB & - & - & - & - \\
\hline & G & nZEB & nZEB & nZEB & nZEB & - & - & - & - & - & - & - & - \\
\hline & $\mathrm{H}$ & nZEB & nZEB & nZEB & nZEB & - & nZEB & nZEB & nZEB & - & - & - & - \\
\hline & IJ & nZEB & nZEB & nZEB & nZEB & $\mathrm{nZEB}$ & nZEB & nZEB & $\mathrm{nZEB}$ & - & - & nZEB & - \\
\hline
\end{tabular}

Table 13b: Additional cost per dwelling to increase the facade performance (zones D2, D1, and E1) and improve the ventilation system (zones $C 1, D 3$ ) to achieve $\mathrm{ZZEB}$ requirements.

\begin{tabular}{ccc}
\hline Climatic zone & Performance level required for the vertical walls & Additional cost per dwelling \\
\hline A4, A3, B4, B3, C4, C3, C2 & $12 \mathrm{~cm}$ of insulation (REFO2). U-value: $0.25 \mathrm{~W} / \mathrm{m}^{2} \cdot \mathrm{K}$ & - \\
\hline C1, D3 & Heat recovery exchanger for ventilation is recommended & $4,049 €$ \\
\hline D2, D1, E1 & $18 \mathrm{~cm}$ of insulation. U-value: $0.18 \mathrm{~W} / \mathrm{m}^{2} \cdot \mathrm{K}$ & $6,126 f$ \\
\hline
\end{tabular}

As shown in Table 13a, dwellings located in the most extreme climatic zones (D1, D2, 3 a na F1) do not achieve the level of energy performance required for nZEB. In these zones, it is necessa y to increase the level of insulation, the initial investment or public aids, as shown in Table 13b listing the additional retrofit and cost needed to achieve $\mathrm{nZEB}$ requirements.

\subsubsection{Level of public aid required to implement a deep retrofit si rategy}

The purpose of this section is to define the total amount of public aid necessary to make the deep-retrofit strategy (REF02) cost-effective (Table 14a). This informa ion could help companies in the construction sector produce business plans focused on energy-driven building renovation, while also encouraging the government to assign public aid more efficient, [49], by seeing if the revenue of taxes derived from the generated work could cover these public subsidies [58]. The calculation is done in an iterative process, increasing the level of subsidies from $0 \%$ to $100 \%$, and checking at each step if the payback time is over 20 years (for each archetype and climatic zone, taking into account the current status and the deep retrofit scenario-REF02).

Table 14a: Level of public aid 1\%, required to implement a deep retrofit strategy (REFO2) with a payback over 20 years with an interest rate of $0.5 \%$. Cells marked wi.h -) correspond to homes that do not need subsidies to recover investment.

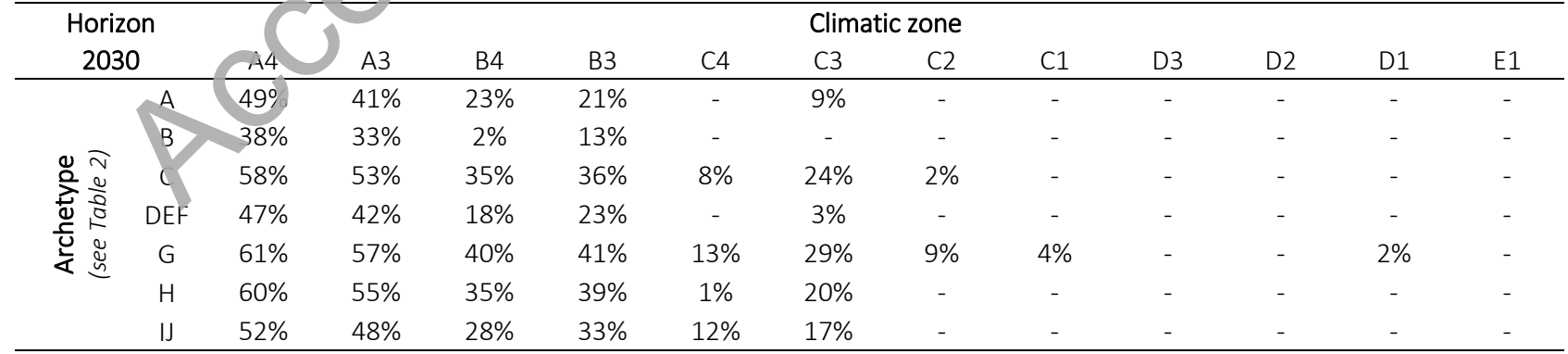

Table 14b: Building element surfaces that could be rehabilitated without public aid by 2030 horizon [thousands of $\mathrm{m}^{2}$ ]. Cells marked with (-) are where public subsidies are required to achieve cost-effectiveness.

\begin{tabular}{|c|c|c|c|c|c|c|c|c|c|c|c|c|c|}
\hline \multirow{2}{*}{\multicolumn{2}{|c|}{$\begin{array}{c}\text { Horizon } \\
2030\end{array}$}} & \multicolumn{12}{|c|}{ Climatic zone } \\
\hline & & A4 & A3 & B4 & B3 & C4 & $\mathrm{C} 3$ & $\mathrm{C} 2$ & $\mathrm{C} 1$ & D3 & D2 & D1 & E1 \\
\hline \multirow{4}{*}{ 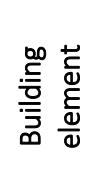 } & Facade & - & - & - & - & 65,053 & 10,913 & 13,080 & 45,578 & 32,959 & 48,158 & 144,764 & 26,910 \\
\hline & Windows & - & - & - & - & 15,133 & 3,321 & 3,280 & 10,427 & 7,155 & 10,509 & 33,419 & 5,852 \\
\hline & Roofs & - & - & - & - & 38,527 & 4,270 & 7,482 & 28,614 & 21,487 & 31,300 & 89,519 & 17,531 \\
\hline & Ground floor & - & - & - & - & 38,527 & 4,270 & 7,482 & 28,614 & 21,487 & 31,300 & 89,519 & 17,531 \\
\hline
\end{tabular}


As shown in Table 14a, only for the residential buildings built in the coldest climatic zones could a deep retrofit strategy (REF02) be applied without subsidies. We can see that the buildings in warm zones (A4, A3, B4 and B3) need to obtain subsidies to ensure cost-effectiveness. Table 14b shows the total surface of building elements that could be renovated if all buildings that do not need public aids implemented the deep retrofit scenario (REF02).

\subsubsection{Payback time estimation for deep retrofit strategy}

This section aims to identify which archetype(s) could be deeply retrofitted (REF02) with a payback over 7 years (short-term horizon) and with or without $25 \%$ of public aid.

Table 15: Payback [years], implementing a deep retrofit REFO2 with and without 25\% of public aid. Values in bold co respond to homes with a payback period equal to or less than 7 years. Values with a star $\left({ }^{*}\right)$ correspond to homes that could hr ve a payback less than 7 years when obtaining $25 \%$ of aid. Remaining archetypes always present a payback of more than 7 years

\begin{tabular}{|c|c|c|c|c|c|c|c|c|c|c|c|c|c|}
\hline \multirow{2}{*}{\multicolumn{2}{|c|}{$\begin{array}{c}\text { Horizon } \\
2030\end{array}$}} & \multicolumn{12}{|c|}{ Climatic zone } \\
\hline & & A4 & $\mathrm{A} 3$ & B4 & B3 & $\mathrm{C4}$ & C3 & $\mathrm{C} 2$ & $\mathrm{C} 1$ & D3 & D2 & D1 & E1 \\
\hline \multirow{7}{*}{ 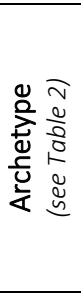 } & A & 17 & 16 & 13 & 13 & 10 & 11 & $9^{*}$ & $9 *$ & 8 & $8^{*}$ & 9* & 7 \\
\hline & B & 15 & 14 & 11 & 12 & $8^{*}$ & $9^{*}$ & $8^{*}$ & $8^{*}$ & & 6 & 7 & 5 \\
\hline & C & 20 & 18 & 15 & 15 & 11 & 13 & 11 & & 9 & $9 *$ & 10 & $8^{*}$ \\
\hline & DEF & 17 & 16 & 12 & 13 & 10 & 11 & $9^{*}$ & 9 & $8^{*}$ & $8^{*}$ & $9 *$ & 7 \\
\hline & G & 21 & 19 & 15 & 16 & 12 & 13 & 11 & & $9 *$ & 10 & 11 & $8^{*}$ \\
\hline & $\mathrm{H}$ & 20 & 19 & 14 & 15 & 11 & 12 & 11 & 1. & $8^{*}$ & $9 *$ & 10 & 7 \\
\hline & IJ & 18 & 17 & 13 & 14 & 12 & 12 & 0 & 10 & $9 *$ & $9 *$ & 10 & 8* \\
\hline
\end{tabular}

As shown in Table 15, only dwellings in the coldest climatic zones (D3, D2, D1 and E1) - in bold - present a payback period (PBP) equal to or less than 7 years. Dwel ings in temperate climatic zones (C4, C3, C2 and C1), corresponding to starred numbers in the table, need $25 \%$ of public aids to reduce their payback to 7 years. The remaining dwellings, in the hottest climatic zones (A4, A3, B4 and B3), need more than $25 \%$ of public aids to reduce their payback to 7 years.

\section{Discussion}

If the horizon of calculation is the mid- to long-term, the cost-optimal methodology prioritizes passive strategies on the building envelope, allowing an important reduction in energy demand (Tables 11a, 11b and 11c). Therefore, work on the envelope of the buildings is a priority to achieve the objectives established by the EU to reduce energy consumption of the built environment.

The cost-o pimal methodology is designed for mid- and long-term investment scenarios, which is why, in the short-term studies, the most cost-effective strategies are always related to improving the efficiency of HVAC systems (Table 12a, 12b). However, by using only active strategies, a maximum of about $40 \%$ energy savings can be expected, while up to $80 \%$ can be achieved by combining passive and active strategies.

During the period of 2004-2013, the average annual increase in the price of energy in Spain has been between $6.5 \%$ and $10.9 \%$ (without considering associated taxes) [82]. The methodology is very sensitive to this parameter. In fact, if the annual energy cost increase exceeds $10 \%$, a deep-retrofit strategy becomes the preferred option, also in the short-term. 
If the interest rate is very high, the most disadvantaged strategy is deep-retrofit due to the higher initial investment. Offering credits with a lower interest rate of 5\% could therefore potentially encourage this type of strategy. This is the case in most EU countries today. Since 2008, probably due to the economic crisis, the interest rate of EURIBOR [83] has remained around 0.5\%. Therefore, the context is ideal for promoting energy rehabilitation projects of existing buildings [84].

As a result of the studies realised with the help of the decision-making tool, if the target is to rehabilitate about 100\% of existing homes (built between 1960 and 2001) from 2016 until 2030 and following a deepretrofit strategy, the Spanish government would have to invest about 29,286 M€ (1,464 M€/year).

The potential housing stock that would achieve the level of requirements of nZEB by implementing a deepretrofit could reach 54.6\% (around 9 million homes; Table 13a), but an additional investment cost (Table $13 \mathrm{~b}$ ) of about 5,000 € per home would be necessary for buildings located in the coldest zones (C1, D1, D2, D3 and E1).

Table 16: Number of homes it would be advisable to refurbish from 2016 until 2030 on the Spanish ter itory.

\begin{tabular}{l|cc}
\hline Number of homes to be refurbished (25\% of public aid to the investment cost) & $9,366,395$ homes & $61 \%$ \\
\hline Primary energy saving [GWh], from 2016 until 2030 & $5,906,915$ & $-79.6 \%$ \\
GHG emissions savings [ $\mathrm{kgCO}_{2}$-eq], from 2016 until 2030 & $1,198,387,749$ & \\
\hline
\end{tabular}

According to the results in Table 16, companies in the construction sector should concentrate, firstly, on homes situated in the coldest zones, such as E1-Leon DI Lugo, C4-Cáceres, C3-Granada and D2-Huesca. Indeed, in these regions, it is cost-effective to propose a deep-retrofit strategy without considering public aid.

\section{Conclusions and recommendatio is}

The literature review suggests that he cost-optimal methodology can perfectly be used to compare different renovation scenarios to mak s at gic decisions assuming an error up to $30 \%$, due to uncertainties in input data, working at the urba sccle and without taking into account different climatic zones [70].

Therefore, the purpose of this study was to investigate if the cost-optimal methodology could successfully be applied at the termorial scale - based on the extrapolation of results from building and neighbourhood scales using more accurate input data than typically used - to obtain an overview of the status of existing buildings ard their potential energy and GHG emissions savings.

This is accomplished by implementing a new systematic strategy, starting from the categorization of the existing housing stock based on the climatic zone and the period of construction, using statistical data and linking this information at different scales - city and building - through energy simulations based on different levels of detail and their extrapolation to the territorial scale.

This research provides empirical evidence that the most effective levers to manage the renewal processes of the built environment to achieve the targets of the EU energy directives are passive strategies acting on buildings' envelopes. Such strategies could give significant benefits including higher levels of energy savings -26 - 
(about 40\%), while increasing interior comfort, quality and value of buildings. It is essential to highlight that to achieve about $80 \%$ savings, it is necessary to consider improvement packages where passive and active strategies are contemplated at the same time, paying special attention to the order of priority in which they are implemented.

The results of this study also indicate that the definition of the horizon of calculation, the macroeconomic parameters, the urban environment and the climatic zone conditions are critical to achieve an accurate level of results and may significantly contribute to progress toward increasing the level of sustainability of the residential building stock of tomorrow.

Taking into account the actual macroeconomic situation in Spain, using a reasonable scenario with 25\% of public aid to the investment cost of the renovation and an interest rate of $0.5 \%$, the potentiar housing stock that would achieve the level of requirements of nZEB by implementing a deep-retrofit could reach $61 \%$ (around 9 million dwellings) with $79.6 \%$ of $\mathrm{PE}(5,906,915 \mathrm{GWh})$ and $\mathrm{CO}_{2}$ emissions $\left(1198,388 \mathrm{tCO}_{2}\right)$ savings.

Our proposed approach, implemented into an Excel-based decision-making tou elying on (and extending) the cost-optimal methodology, can support urban planners make trategic decisions towards more sustainable urban renewal processes of the building stock. It can moreover help the construction sector adapt their business goals to promote energy renewal projects.

Derived from the main results of this study, a list of recomm endations to encourage owners to undertake a renovation of their building is proposed:

- Public aid to subsidize the initial investment;

- More attractive credits to implement passive strategies;

- Increase in value-added tax (VAT) on less efficient HVAC systems;

- Reduction in VAT, to promote the use of more ecological certified products;

- Campaign to promote the rehabilitation of buildings, lowering the Property Tax (IBI) during the years in which investment is being rocovered;

- Promote enersy rehabilitation of entire buildings, offering communities city-funded advice and management. The owners would only have to pay a fee to the city council, equivalent to the monthly savings of the overal energy bill. The preliminary study would be to calculate the monthly fee that a community could pay, based on energy savings achieved after rehabilitation. Therefore, they would know whether they can pay the investment through a soft loan; if not, the administration should finance the rest.

Future development of this research will look into incorporating more case studies the neighbourhood and building scales, using accurate energy simulation and involving more building-typology diversity, with the aim to better calibrate the decision-making tool for territorial-scale applications. Implementing the calculation algorithm into a geographic information system (GIS) platform could be envisioned mainly for enhanced visualization. 
To further refine our building stock database, satellite-derived data could be used. Along the same line of thought, optimization methods could be employed to better identify cost-optimal strategies [32].

The inclusion of Building-Integrated Photovoltaic (BIPV) into the renewable energy strategies is also planned, in order to achieve Low-Carbon horizon targets in EU countries [85].

Finally, in terms of economic outputs, it would be advisable to calculate the government incomes due to the VAT (e.g. through increased retrofit-related work), which could be superior to the total amount of public aids to the dwelling owners, as demonstrated in [58].

\section{Acknowledgements}

The authors would like to express their gratitude to the National Research Programme "Energ Ty rnaround" (NRP 70) of the Swiss National Science Foundation (SNSF) for their financial support to the ACTIVE INTERFACES research project, which represents a continuation of certain reflexions unuertaken within the framework of this study.

\section{Abbreviations}

$\begin{array}{ll}\text { CDD } & \text { cooling degree days } \\ \text { CE3x } & \text { official software for energy performance certification } \\ \text { CTE } & \text { technical building code } \\ \text { DHW } & \text { domestic hot water } \\ \text { EEM } & \text { energy-efficient measures } \\ \text { EPBD } & \text { energy performance of buildings dir } \\ \text { EPC } & \text { energy performance certification } \\ \text { EU } & \text { European Union } \\ \text { GIS } & \text { geographic information system } \\ \text { GHG } & \text { greenhouse gas } \\ \text { GTR } & \text { rehabilitation working group } \\ \text { HDD } & \text { heating degree days } \\ \text { HVAC } & \text { heating ventilation and air conditioning } \\ \text { LCA } & \text { life-cycle asses ment } \\ \text { LCC } & \text { life-cycle cost } \\ \text { LOD } & \text { level of det il } \\ \text { MF } & \text { multi- anil } \\ \text { MS } & \text { member states } \\ \text { NPV } & \text { net present value } \\ \text { nZEB } & \text { nearly zero energy buildings } \\ \text { ORIG } & \text { current status scenario } \\ \text { PE } & \text { primary energy } \\ \text { RD } & \text { royal decree } \\ \text { REF01 } & \text { minor retrofit scenario } \\ \text { REFO2 } & \text { deep retrofit scenario } \\ \text { RET } & \text { renewable energy technologies } \\ \text { SF } & \text { single-family } \\ \text { PBP } & \text { payback period } \\ \text { TABULA } & \text { typology approach for building stock energy assessment } \\ \text { VAT } & \text { value-added tax } \\ & \end{array}$




\section{References}

[1] Comision Europea, Energía, 2014. doi:10.2775/60262.

[2] Idae, Plan de ahorro y eficiencia energética 2011-20 (Spanish National Renewable Energy Plan (NREP) 20112020), (2011) 268. http://www.idae.es/uploads/documentos/documentos_11905_PAEE_2011_2020._A2011_A_a1e6383b.pdf.

[3] European Commission, Hoja de Ruta de la Energía para 2050, COM(2011) 885 Final. (2011) 23. http://eurlex.europa.eu/LexUriServ/LexUriServ.do?uri=COM:2011:0885:FIN:ES:PDF.

[4] Suisse Energie, La société à 2000 watts, (2016). http://www.2000watt.ch/fr/ (accessed January 20, 2016).

[5] SFOE, Energy Strategy 2050, 2015. http://www.bfe.admin.ch/themen/00526/00527/index.html?lang=en (accessed September 22, 2015).

[6] H. Akbari, M. Santamouris, Z. Ma, P. Cooper, D. Daly, L. Ledo, Existing building retrofits: Methodology and stateof-the-art, Energy Build. 55 (2012) 889-902. http://www.sciencedirect.com/science/article/pii/S0378778812004227 (accessed December 17, 2013).

[7] M. Gangolells, M. Casals, N. Forcada, M. Macarulla, E. Cuerva, Energy mapping of existing b illa ing tock in Spain, J. Clean. Prod. 112 (2016) 3895-3904. doi:10.1016/j.jclepro.2015.05.105.

[8] A. Brandão de Vasconcelos, M.D. Pinheiro, A. Manso, A. Cabaço, EPBD cost-optimal met oc'ology: application to the thermal rehabilitation of the building envelope of a Portuguese residential reference building, Energy Build. 111 (2015) 12-25. doi:(under review).

[9] IEA, Energy Performance Certification of Buildings - A Policy Tool to Improve Energy Efficiency, (2010) 64. http://www.iea.org/publications/freepublications/publication/building__er_ification.pdf.

[10] IEA, Transition to Sustainable Buildings, 2013. doi:10.1787/978926+202955-en.

[11] A. Uihlein, P. Eder, Policy options towards an energy efficient resiaential building stock in the EU-27, Energy Build. 42 (2010) 791-798. doi:10.1016/j.enbuild.2009.11.026.

[12] E. Stocker, M. Tschurtschenthaler, L. Schrott, Cost-optima renovation and energy performance: Evidence from existing school buildings in the Alps, Energy Build. 100 (2015) 20-26. doi:10.1016/j.enbuild.2015.04.005.

[13] Instituto Nacional de Estadistica, 2001 Population nd Housing Census, (2001). http://www.ine.es/.

[14] Instituto Nacional de Estadistica, 2011 Population and Housing Census, (2011). http://www.ine.es/jaxi/Tabla.htm?pa h-/t20/e244/edificios/p02/l0/\&file=00004.px.

[15] M. Gangolells, M. Casals, Resilience to creasing temperatures: residential building stock adaptation through codes and standards, Build. Res If. 40 (2012) 1-20. doi:10.1080/09613218.2012.698069.

[16] BPIE (Building Performance Inct - ut Europe), Nearly Zero Energy Buildings Definitions across Europe, (2015) 8. http://bpie.eu/uploads/lib,document/attachment/132/BPIE_factsheet_nZEB_definitions_across_Europe.pdf.

[17] European Parliament, Directive 2010/31/EU of the European Parliament and of the Council of 19 May 2010 on the energy performa ce of buildings EPBD (recast), Off. J. Eur. Union. (2010) 13-35.

doi:doi:10.3000/17/252555.L_2010.153.eng.

[18] Spanish bui ding regulation, Documento básico HE ahorro de energía, Código Técnico La Edif. Doc. Básico HE Ahorr. Energla. 2013 (2013) 1-70. http://www.codigotecnico.org/web/recursos/documentos/.

[19] $M \mathrm{NL}^{-1} \mathrm{IR}$, Current state of the energy certification of buildings. Data from regional governments (Estado de la cer iricaci on energ etica de los edificios. Datos CCAA), 2015.

http://www.minetur.gob.es/energia/desarrollo/EficienciaEnergetica/CertificacionEnergetica/Documentos/Docu ments/Informe-seguimiento-certificacion-energetica-V2.pdf.

[20] Spanish government, Real Decreto 235 / 2013, de 5 de abril , por el que se aprueba el procedimiento básico para la certificación de la eficiencia energética., (2013) 1-14.

[21] IDAE, Energy performance rating for existing buildings (Escala de calificaci on energetica para edificios existentes), 2011.

http://www.minetur.gob.es/energia/desarrollo/EficienciaEnergetica/CertificacionEnergetica/DocumentosRecon ocidos/OtrosDocumentos/Calificación energética. Viviendas/Escala_Calif_Edif_Existentes_accesible.pdf.

[22] BPIE (Building Performance Institute Europe), Europe's buildings under the microscope. A country-by-country review of the energy performance of buildings., 2011.

[23] BPIE (Building Performance Institute Europe), Principles for nearly zero-energy buildings, paving the way for effective implementation of policy requirements, 2011. http://www.bpie.eu/nearly_zero.html. 
[24] G. Dall'O', A. Galante, G. Pasetti, A methodology for evaluating the potential energy savings of retrofitting residential building stocks, Sustain. Cities Soc. 4 (2012) 12-21. doi:10.1016/j.scs.2012.01.004.

[25] Spanish government, Real Decreto 2429/79 - Norma Basica de la Edificacion NBE-CT-79, sobre Condiciones Térmicas en los edificios., (1979) 27. https://www.boe.es/buscar/doc.php?id=BOE-A-1979-24866.

[26] Ministerio de vivienda, REAL DECRETO 314/2006, de 17 de marzo, por el que se aprueba el Código Técnico de la Edifi- cación, Real Decreto. (2006) 11816-11831. http://www.codigotecnico.org/web/recursos/documentos/.

[27] Spanish government, RITE 2007. Reglamento de instalaciones térmicas en los edificios, Bol. Of. Del Estado. (2007) 35931-35984.

[28] Spanish government, REAL DECRETO 47/2007, Bol. Of. Del Estado. 27 (2007) 4499-4507.

[29] Spanish government, Ley de Rehabilitación, Regeneración y Renovación Urbana, (2013) 47964-48023.

[30] J.S. Bourrelle, I. Andresen, A. Gustavsen, Energy payback: An attributional and environmentally focused approach to energy balance in net zero energy buildings, Energy Build. 65 (2013) 84-92. doi:10.1016/j.enbuild.2013.05.038.

[31] E. Pikas, M. Thalfeldt, J. Kurnitski, Cost optimal and nearly zero energy building solutions for office bu ildings, Energy Build. 74 (2014) 30-42. doi:10.1016/j.enbuild.2014.01.039.

[32] O. Pombo, K. Allacker, B. Rivela, J. Neila, Sustainability assessment of energy saving me sures: a multi-criteria approach for residential buildings retrofitting-A case study of the Spanish housing scock, cnergy Build. (2016). doi:10.1016/j.enbuild.2016.01.019.

[33] I. Zacà, D. D’Agostino, P.M. Congedo, C. Baglivo, Assessment of cost-optimality a nd technical solutions in high performance multi-residential buildings in the Mediterranean area, Energ, Bulıt. 102 (2015) 250-265. doi:10.1016/j.enbuild.2015.04.038.

[34] European Parliament, Directive 2012/27/EU of the European Parlia mentand of the Council of 25 October 2012 on energy efficiency, Off. J. Eur. Union. (2012) 1-56. doi:10.3000/19770677.L_2012.315.eng.

[35] BPIE (Building Performance Institute Europe), Implementing the cost-optimal methodology in EU countries : Lessons learned from three case studies, 2013.

[36] S. Aguacil, Evaluation of the cost-optimal methodology for energy rehabilitation of buildings and objective assessment NZEB (Nearly Zero Energy Buildings)., Iniversitat Politecnica de Catalunya, 2013. http://hdl.handle.net/2099.1/20487.

[37] A. Brandão de Vasconcelos, M.D. Pinheiro, A Manso, A. Cabaço, A Portuguese approach to define reference buildings for cost-optimal methodolog ies, Appl. Energy. 140 (2015) 316-328. doi:10.1016/j.apenergy.2014.11035.

[38] P.M. Congedo, C. Baglivo, D. D' Agos tino, I. Zacà, Cost-optimal design for nearly zero energy office buildings located in warm climates, Ene gy. 1 (2015) 967-982. doi:10.1016/j.energy.2015.08.078.

[39] I. Kovacic, M. Summer, Achammer, Strategies of building stock renovation for ageing society, J. Clean. Prod. 88 (2015) 349-357 dol. 0.1016/j.jclepro.2014.04.080.

[40] V. Corrado, I. Barlarini, Paduos, Assessment of cost-optimal energy performance requirements for the Italian residential building stock, Energy Procedia. 45 (2014) 443-452. doi:10.1016/j.egypro.2014.01.048.

[41] S. Domirgo-_igoyen, A. Sánchez-Ostiz, J.S. Miguel-Bellod, Cost-effective Renovation of a Multi-residential Building in S jain through the Application of the IEA Annex 56 Methodology, Energy Procedia. 78 (2015) 2385230 a i: 10.1016/j.egypro.2015.11.194.

[42] L. Aelenei, S. Paduos, H. Petran, J. Tarrés, A. Ferreira, V. Corrado, et al., Implementing Cost-optimal Methodology in Existing Public Buildings, in: Energy Procedia, Elsevier B.V., 2015: pp. 2022-2027. doi:10.1016/j.egypro.2015.11.197.

[43] E.G. Dascalaki, K.G. Droutsa, C.A. Balaras, S. Kontoyiannidis, Building typologies as a tool for assessing the energy performance of residential buildings - A case study for the Hellenic building stock, Energy Build. 43 (2011) 3400-3409. doi:10.1016/j.enbuild.2011.09.002.

[44] I. Ballarini, S.P. Corgnati, V. Corrado, Use of reference buildings to assess the energy saving potentials of the residential building stock: The experience of TABULA project, Energy Policy. 68 (2014) 273-284. doi:10.1016/j.enpol.2014.01.027.

[45] Intelligent Energy Europe, Typology Approach for Building Stock Energy Assessment - TABULA Database (National Building Typology), (2016). http://episcope.eu/building-typology/ (accessed November 14, 2016).

[46] K. Fabbri, L. Tronchin, V. Tarabusi, Energy Retrofit and Economic Evaluation Priorities Applied at an Italian Case 
Study, Energy Procedia. 45 (2014) 379-384. doi:10.1016/j.egypro.2014.01.041.

[47] E. Pikas, J. Kurnitski, R. Liias, M. Thalfeldt, Quantification of economic benefits of renovation of apartment buildings as a basis for cost optimal 2030 energy efficiency strategies, Energy Build. 86 (2015) 151-160. doi:10.1016/j.enbuild.2014.10.004.

[48] P. (Lucerne U. of A.S. and A. (Hslu)) Schwehr, R. (Lucerne U. of A.S. and A.-C. Fischer, Building Typology and Morphology of Swiss Multi-Family Homes 1919 - 1990, (2010) p.11.

[49] eceee, Cost optimal building performance requirements: Calculation methodology for reporting on national energy performance requirements on the basis of cost optimality withing the framework of the EPBD, Stockholm, Sweden, 2011. www.eceee.org.

[50] M.J.N. Oliveira Panão, M.P. Rebelo, S.M.L. Camelo, How low should be the energy required by a nearly ZeroEnergy Building? The load/generation energy balance of Mediterranean housing, Energy Build. 61 (2013) 161171. doi:10.1016/j.enbuild.2013.02.031.

[51] A. Parekh, Development of archetypes of building characteristics libraries for simplified energy use valuation of houses, Ninth Int. IBPSA Conf. (2005) 921-928. doi:10.1.1.470.363.

[52] L.G. Swan, V.I. Ugursal, Modeling of end-use energy consumption in the residential sector: A r vie wof modeling techniques, Renew. Sustain. Energy Rev. 13 (2009) 1819-1835. doi:10.1016/j.rser.2008.09.033.

[53] F. Ascione, N. Bianco, C. De Stasio, G.M. Mauro, G.P. Vanoli, A new methodology for cos top timal analysis by means of the multi-objective optimization of building energy performance, Energy 3. 88 (2015) 78-90. doi:10.1016/j.enbuild.2014.11.058.

[54] P. Aparicio, J. Guadix, J. Salmerón, F.J. Sánchez, An integrated optimisation methou for residential building design. A case study in Spain, Energy Build. 80 (2014) 158-168. doi:10.1016/i. enbuild.2014.05.020.

[55] E. Asadi, M.G. da Silva, C.H. Antunes, L. Dias, A multi-objective opt miza ion model for building retrofit strategies using TRNSYS simulations, GenOpt and MATLAB, Build. Enviro 56 (20:12) 370-378. doi:10.1016/j.buildenv.2012.04.005.

[56] S. Attia, M. Hamdy, W. O’Brien, S. Carlucci, Assessing gaps nd needs for integrating building performance optimization tools in net zero energy buildings design, Ene gy Build. 60 (2013) 110-124. doi:10.1016/j.enbuild.2013.01.016.

[57] S.H. Lee, T. Hong, M.A. Piette, Review of existin。 en rergy retrofit tools. Lawrence Berkeley National Laboratory, 2014. https://buildings.Ibl.gov/sites/all/files/tic nzhen_hong_-_review_of_existing_energy_retrofit_tools.pdf.

[58] P. Bermejo, El «renove de casas», La Razon (2014) 44-45.

[59] P. a. Fokaides, A.M. Papadopou'os, Cos optimal insulation thickness in dry and mesothermal climates: Existing models and their improvement Lnergy Build. 68 (2014) 203-212. doi:10.1016/j.enbuild.2013.09.006.

[60] P. Steskens, Y. Vanhellemo $\pi$, . Noels, N. Van Den Bossche, A decision making tool for the energy efficient refurbishment of reside tic' bu dings, Energy Procedia. 0 (2015) 997-1002. doi:10.1016/j.egypro.2015.11.043.

[61] T. Ashrafian, A.Z. Yilrnaz, S.P. Corgnati, N. Moazzen, Methodology to define cost-optimal level of architectural measures for energy fficient retrofits of existing detached residential buildings in Turkey, Energy Build. 120 (2016) 58-77, a 10.1016/j.enbuild.2016.03.074.

[62] EFINOVATIC CE 3x, (2016). http://www.efinovatic.es/.

[63] GPCe, Fund cion CONAMA, Rehabilitation Working Group (GTR), (2016). http://www.gbce.es/en/pagina/gtrgo Is and-targets (accessed January 19, 2016).

[64] A. Cuchí, P. Sweatman, GTR report 2011: A national perspective on Spain's buildings sector. A roadmap for a new housing sector., 2011.

[65] A. Cuchí, P. Sweatman, GTR report 2012: A national perspective on spain's building sector. Action plan for a new housing sector., 2012.

[66] A. Cuchí, P. Sweatman, GTR report 2014: Strategy for buildings renovation. Keys to transform spain's building sector., 2014.

[67] European Commission, EUROSTAT, Prod. Constr. down by 0.4\% Euro Area. (2015). http://ec.europa.eu/eurostat/en/web/products-press-releases/-/4-18112015-AP (accessed January 18, 2016).

[68] A. Cuchí, P. Sweatman, A. Pagès, Scenarios for the reduction of greenhouse gas (GHG) emissions for the residential sector in Spain., 2012.

[69] A. Enseling, T. Loga, Implementing the cost-optimal methodology in EU countries - Case study Germany, 2012. 
[70] M. Jakob, Marginal costs and co-benefits of energy efficiency investments: The case of the Swiss residential sector, Energy Policy. 34(2) (2006) 172-187. http://doi.org/10.1016/j.enpol.2004.08.039.

[71] M. Kapsalaki, V. Leal, M. Santamouris, A methodology for economic efficient design of Net Zero Energy Buildings, Energy Build. 55 (2012) 765-778. doi:10.1016/j.enbuild.2012.10.022.

[72] J. Kurnitski, How to calculate cost optimal nZEB energy performance ?, REHVA J. (2011) 36-41.

[73] F. Flourentzou, C.-A. Roulet, Elaboration of retrofit scenarios, Energy Build. 34 (2002) 185-192. http://www.sciencedirect.com/science/article/pii/S0378778801001062 (accessed December 17, 2013).

[74] CYPE Ingenieros, Database of construction products and systems (CYPE Ingenieros), (2016). http://www.generadordeprecios.info/ (accessed October 18, 2016).

[75] COP - Coefficient of performance, (2016). https://en.wikipedia.org/wiki/Coefficient_of_performance (accessed November 10, 2016).

[76] SEER - Seasonal energy efficiency ratio, (2016). https://en.wikipedia.org/wiki/Seasonal_energy_efficiency_ratio (accessed October 11, 2016).

[77] E. Rey, S. Lufkin, C. Ballif, R. Wuestenhagen, S. Wittkopf, J.-P. Bacher, Building integrated photol oltaics | ACTIVE INTERFACES, National Research Programmes NRP 70 «Energy Turnaround» and NRP 71 «Managing Energy Consumption», Luzern, 2015.

[78] D. D'Agostino, Assessment of the progress towards the establishment of definitions of Neany Zero Energy Buildings (nZEBs) in European Member States, J. Build. Eng. 1 (2015) 20-32. doi:10.1016/j.jobe.2015.01.002.

[79] Passive House Institute, (2016). http://www.passivehouse.com/ (accessed Nove nber 8, 2016).

[80] Comunidad de Madrid, Guia del estándar PassivHaus; edificios de consumo energético casi nulo, (2011) 203.

[81] P. Hernandez, P. Kenny, From net energy to zero energy buildings Perir ing life cycle zero energy buildings (LCZEB), Energy Build. 42 (2010) 815-821. doi:10.1016/j.enbuild 2009.1.2. 001.

[82] National Energy Commission, Monthly Bulletin of electrical and e conomic indicators (2013 - 2016), 2016. https://www.cnmc.es/es-es/energía/energíaeléctrica/indicádoreseléctricos.aspx.

[83] Triami Media, Euribor-rates, (2016). http://www.eurib or-rates.eu (accessed October 11, 2016).

[84] I.U. The Economist, Investing in energy efficiency Eu ope 's buildings - A view from the construction and real estate sectors, Econ. Intell. Unites Ltd. (2013) 1-17.

[85] S. Aguacil, S. Lufkin, E. Rey, Towards integrated design strategies for implementing BIPV systems into urban renewal precesses: First case study in Ve chatel (Switzerland), in: G. Habert, A. Schlueter (Eds.), Sustain. Built Environ. Reg. Conf. Zurich 2016 Zurich 2016: pp. 234-239. doi:10.3218/3774-6. 